\title{
History of the first 30 years of the Canadian Association of Gastroenterology
}

\author{
L'Association canadienne de \\ gastroentérologie, \\ les 30 premières années
}

IVAN T BECK, MD, PHD, FRCPC, FACP, MACG

$\mathrm{I}$ N 1992 THE CANADIAN ASSOCIATION 1 of Gastroenterology (CAG) reached its 30th anniversary. Much has happened and many changes occurred during the first 30 years of this Association; this anniversary presented an opportune time to document some of the major events that occurred during these years.

My stimulus to become involved in this undertaking was in 1989 when the Royal College of Physicians and Surgeons of Canada (RCPSC) requested Dr Iain Cleator, our President, to contribute a chapter to the book, Medical Specialty Societies of Canada, edited by Dr Tom M Morley (1). As I was the archivist and historian of the CAG, Dr Cleator and the Governing Board of the Association requested that I should prepare that chapter. Once I started to review the documents and remembered and relived some of the major events which constitute the history of the CAG, my enthusiasm rose, and I became more and more involved and stimulated to write the chapter on the CAG for Dr Morley's book. Once completed, this was submitted and the book was published in 1991 (1).

I feel that much has happened in 1990 and 1991 to warrant an extension to include the first 30 years of the CAG and thus finish the history at an important anniversary. Furthermore, because of the size of Dr Morley's book, much of my research could not be included in the manuscript submitted to the College. While I was writing the above chapter, I talked to several members of the Board, before I was approached by Dr Eldon Shaffer, the 29th President of

Queen's University, Kingston, Ontario

Correspondence and reprints: Dr Ivan T Beck, Archivist and Historian, Canadian Association of Gastroenterology, Emeritus Professor of Medicine and Physiology, Queen's University, Kingston, Ontario K7L 5G2

the Association, who indicated that the Board of the CAG would like me to write an extended book-size history of our first 30 years. I have now started writing this manuscript. However this monograph may not be ready and available to our membership for some time. Therefore I decided to write this abbreviated form of our history, which can be made available rapidly, hopefully for your enjoyment. Some of this material was included in the chapter of Dr Morley's book and he gave me permission to reuse this in the present text. The present article provides an extension on the chapter, and a considerable part of this article is based on my research carried out for the larger monograph that I have now started to write.

The present short essay on our history has been compiled in the hope that younger members of the CAG will understand how some of the problems that the CAG is dealing with today originated from what happened in the past. I also hope that this history may 
TABLE 1

List of Canadian general internists and surgeons who expressed a special interest in gastroenterology before 1950

\begin{tabular}{l} 
Edmonton \\
Dr Walter C MacKenzie \\
Kingston \\
Dr Malcolm Brown \\
Montreal \\
Dr Antonio Cantero \\
Dr Yves Chaput \\
Dr Roger B Dufresne \\
Dr Gerald W Halpenny \\
Dr Paul Letendre* \\
Dr Gavin Miller \\
Dr Clarence Tidmarsh* \\
Dr Jacques Tremblay \\
Dr Saint-Jean Desrosiers* \\
Quebec \\
Dr Jean-Paul Dugal* \\
Saskatoon \\
Dr Douglas J Buchan \\
Toronto \\
Dr John R Bingham \\
Dr Ernest E Cleaver \\
Dr H Hetherington \\
Dr Ernest J Maltby \\
Dr Fred Rolph \\
Dr Keith J Roy Wightman \\
Vancouver \\
Dr MM Baird \\
Dr E Christopherson \\
Dr Rocke Robertson \\
Dr Roger Wilson \\
Winnipeg \\
Dr Neil John McLean \\
Dr C Burton Stewart \\
Dr PHT Thorlakson \\
\hline
\end{tabular}

*Indicates that their practice consisted mainly of patients with gastroenterological problems

help our recent members to understand the basic philosophy of the Association and help them to appreciate how, in spite of its shortcomings, the CAG has contributed to the development of $\mathrm{Ca}$ nadian gastroenterology.

At the same time, more senior members of the Association will relive some of the exciting times when they and their colleagues were involved in the creation and the development of the ideas that founded the basis of the future evolution of our Association.

At first I found it difficult to write an unbiased history of the CAG. This mainly is because I have been involved
TABLE 2

List of Canadian gastroenterologists who pioneered the subspecialty of gastroenterology in the early 1950 s

\begin{tabular}{l} 
Halifax \\
Dr Robert C Dickson \\
Dr Robert M MacDonald \\
Quebec \\
Dr Jean-Paul Dugal \\
Montreal \\
Dr Richard D McKenna \\
Dr Miller C Ballem \\
Dr Jacques O Gagnon \\
Dr Paul Letendre \\
Dr Morris Miller \\
Dr Gordon Young \\
Toronto \\
Dr Charles B Brown \\
Dr John R Bingham \\
Dr Louis J Cole \\
Dr Robert C Dickson \\
Dr John M Finlay \\
Dr Paul M O'Sullivan \\
Winnipeg \\
Dr Duncan L Kippen \\
Dr Wendall McLeod \\
Edmonton \\
Dr J Alan L Gilbert \\
Vancouver \\
Dr Abraham Bogoch \\
\hline
\end{tabular}

with the Association for such a long time. I was one of the founding members of the CAG and served as its first Secretary from 1961 to 1965 . After this I was elected Vice-President, then President-Elect and finally President in 1967. Following this I was on the Governing Board as Past-President in 1968 and as Chairman of different committees on and off between 1968 and 1980 . In 1980, mainly because of my intimate knowledge of the CAG's background, I was asked to serve as archivist and historian, and as such I am a nonvoting member of the Board. Still, I have been present at most of the major discussions, and was able to contribute to some of these.

Thus, I found that in writing this review I have had some difficulties dealing only with what is written in the minutes and correspondences, without remembering the discussions that occurred around most of the decisions made. Therefore, in order to avoid per-
TABLE 3

Gastroenterologists who regularly attended the Montreal-Interhospital Gastrointestinal Journal Club

\section{Royal Victoria \\ Richard D McKenna \\ Miller C Ballem \\ Ivan T Beck \\ Montreal General \\ Douglas G Kinnear \\ St Mary's \\ Ivan T Beck \\ Jeno Solymar \\ Maisonneuve \\ Florent Thibert \\ Queen Elizabeth \\ Robert Bourne \\ Jewish General \\ Morris Miller \\ Isadore W Weintrub \\ Verdun General \\ Jacques O Gagnon \\ Hotel Dieu \\ Paul Letendre}

sonal bias, I had to research everything I state here and assess carefully what was actually written in the minutes and the correspondences, and what I seem to have remembered.

Another question that I had to decide on was whether I should write this as a personal recollection, and thus write about my own contributions in the first person (eg, I suggested ) or in a more detached fashion (eg, sug gested by Dr Beck ). I decided on the second approach so that the history should not only be written in an unbiased fashion, but should also appear to be so. Another decision I had to make was whether to use short names for people I have known very well (eg, Dick McKenna versus Dr Richard D McKenna ). To make this history factual but still easy to read, I have decided that after having referred to the short names in brackets at the first occasion of mentioning the name of a person, to use intermittently either the full or short names of the participants. Hopefully, in addition to making this short synopsis accurate, I have succeeded to make it pleasurable and easy to read. 


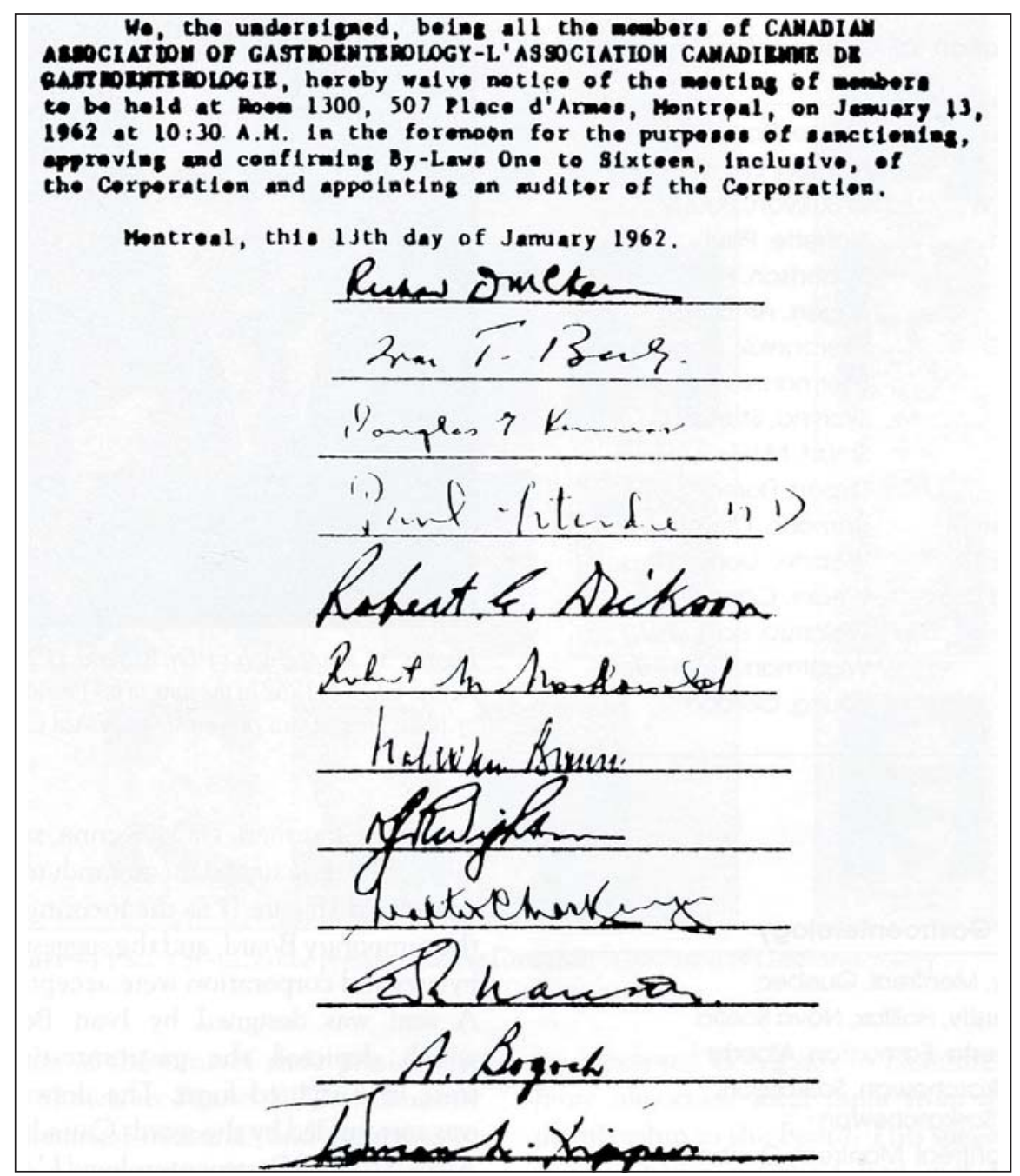

Figure 1) Document of incorporation of the Canadian Association of Gastroenterology/L'Association canadienne de gastroenterologie. Signatures: Drs Richard D McKenna, Ivan T Beck, Douglas G Kinnear, Paul Letendre, Robert C Dickson, Robert M MacDonald, Malcolm Brown, KJR Wightman, Walter CMacKenzie, Eric M Nanson, A Bogoch, Duncan M Kippen

\section{ORGANIZATION OF THE ASSOCIATION}

Foundation of the Association

Specialization in the different areas of internal medicine was not encouraged in Canada during the first half of this century. There were, however, in most major cities, physicians and surgeons who developed a special interest in gastroenterology besides practising general internal medicine or general surgery (Table 1). Modern gastroenterology based on the concepts of clinical investigation and the results of newer technical procedures started to develop only during the second part of this century. Based on better understanding of the pathophysiology of digestive dis- eases, advances in gastroenterology during the past 40 years were rapid.

During the 1950s, a younger group of physicians who confined their practice to gastroenterology (Table 2) started to feel that there was a need for a subspecialty society. At first, the annual meeting of the American Gastroenterological Association (AGA) was the common meeting place for Canadian gastroenterologists. Dr Richard D (Dick) McKenna, Chairman of the Division of Gastroenterology at the Royal Victoria Hospital of McGill University (Montreal, Quebec) was Treasurer of the AGA. At each of the Annual Meetings of the AGA he organized a gathering of all Canadians attending the convention, and this interaction

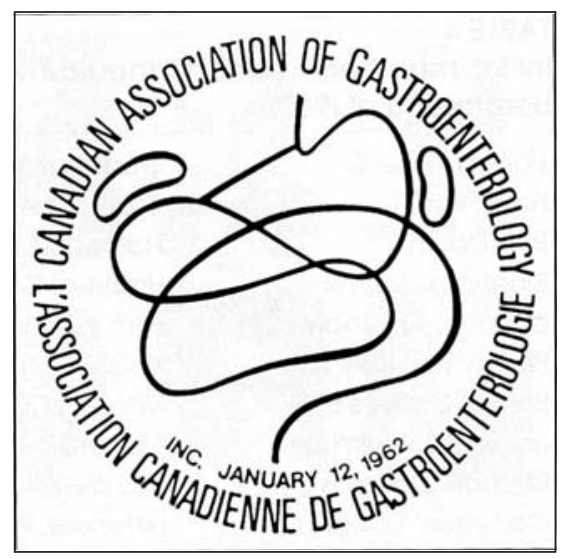

Figure 2) Seal of the Canadian Association of Gastroenterology

among Canadians from all parts of the country was one of the factors which provided impetus for establishment of the CAG.

Another group which was instrumental in starting the CAG was the Montreal Interhospital Gastrointestinal Journal Club. Meetings of this group were held in Dr McKenna's home where, in a pleasant atmosphere, Montreal gastroenterologists (English and French) exchanged information on exciting new developments in the field (Table 3). One evening, after a Journal Club meeting, Dick McKenna, Douglas (Doug) Kinnear and Ivan Beck started to plan the establishment of the CAG. Dick McKenna wrote to his friends and soon reported that there was encouraging interest throughout the country.

On June 21, 1961, this interested group met at the meeting of the Canadian Medical Association (CMA) at the Queen Elizabeth Hotel in Montreal and decided to establish the Canadian Association of Gastroenterology/L'Association canadienne de gastroentérologie. The Association was to be built on broad principles. It was to be bilingual and to include individuals of different disciplines: physicians, surgeons, pediatricians, radiologists and basic scientists. A Committee of Incorporation, consisting of Dick McKenna, Ivan Beck, Doug Kinnear and Paul Letendre, was formed. Letters patent incorporating the Corporation under the provisions of Part II of the Companies Act were issued by the Secretary of 
TABLE 4

Initial members of the Canadian Association of Gastroenterology (joined before end of 1962)

\begin{tabular}{lll}
\hline Ballem, Miller C & Gagnon, Jacques O & Munro, Douglas \\
Beck, Ivan T & Gilbert, J Alan L & Nanson, Eric M \\
Bell, David & Halpenny, Gerald W & O'Sullivan, Paul M \\
Bingham, John R & Harrison, Cameron & Pichette, Paul \\
Bogoch, Abraham & Hildes, John A & Robertson, H Rocke \\
Brown, Berkeley C & Hogarth, Jean & Rogers, Arnold G \\
Brown, Charles B & Kinnear, Douglas G & Sherbaniuk, Richard W \\
& & \\
Brown, Malcolm G & Kippen, Duncan L & Sherman, Ludwig \\
Buchan, Douglas J & Kowalewski, KP & Skoryna, Stanley C \\
Cameron, Douglas G & Letendre, Paul & Smart, MJ \\
Cantero, Antonio & Lind, James F & Thibert, Florent \\
Chaput, Yves & MacDonald, Robert M & Tidmarsh, Clarence J \\
Currie, Don J & MacKenzie, Walter C & Webster, Donald R \\
Daniel, Edwin E & McKenna, Richard D & Weder, Carmen H \\
Dickson, Robert C & McKenzie, Allan D & Weintrub, Isadore W \\
Dufresne, Roger B & Miller, Morris & Wightman, Keith J Roy \\
Dugal, Jean-Paul & Miller, G Gavin & Young, Gordon \\
Finlay, John M & & \\
\hline
\end{tabular}

TABLE 5

Presidents of the Canadian Association of Gastroenterology

\begin{tabular}{|c|c|c|}
\hline 1961 & Richard D McKenna & McGill University, Montreal, Quebec \\
\hline 1962 & Robert C Dickson & Dalhousie University, Halifax, Nova Scotia \\
\hline 1963 & Walter C MacKenzie & University of Alberta, Edmonton, Alberta \\
\hline 1964 & Eric M Nanson & $\begin{array}{c}\text { University of Saskatchewan, Saskatoon, } \\
\text { Saskatchewan }\end{array}$ \\
\hline 1965 & Paul Letendre & Université de Montréal, Montreal, Quebec \\
\hline 1966 & Keith J Roy Wightman & University of Toronto, Toronto, Ontario \\
\hline 1967 & Ivan T Beck & Queen's University, Kingston, Ontario \\
\hline 1968 & Abraham Bogoch & University of British Columbia, Vancouver, BC \\
\hline 1969 & Douglas G Kinnear & McGill University, Montreal, Quebec \\
\hline 1970 & J Alan L Gilbert & University of Alberta, Edmonton, Alberta \\
\hline $197 \mid$ & John M Finlay & University of Toronto, Toronto, Ontario \\
\hline 1972 & James F Lind & University of Manitoba, Winnipeg, Manitoba \\
\hline 1973 & Joseph J Sidorov & Dalhousie University, Halifax, Nova Scotia \\
\hline 1974 & Jacques O Gagnon & Université de Montréal, Montreal, Quebec \\
\hline 1975 & Richard R Gillies & University of Ottawa, Ottawa, Ontario \\
\hline 1976 & Bernard J Perey & Université de Sherbrooke, Sherbrooke, Quebec \\
\hline 1977 & Leslie S Valberg & University of Western Ontario, London, Ontario \\
\hline 1978 & Wilfred M Weinstein & University of Alberta, Edmonton, Alberta \\
\hline 1979 & Florent Thibert & Université de Montréal, Montreal, Quebec \\
\hline 1980 & Jacques Kessler & McGill University, Montreal, Quebec \\
\hline $198 \mid$ & Gordon G Forstner & University of Toronto, Toronto, Ontario \\
\hline 1982 & Cameron Harrison & University of British Columbia, Vancouver, BC \\
\hline 1983 & Laurington R DaCosta & Queen's University, Kingston, Ontario \\
\hline 1984 & William C Watson & University of Western Ontario, London, Ontario \\
\hline 1985 & Claude C Roy & Université de Montréal, Montreal, Quebec \\
\hline 1986 & C Noel Williams & Dalhousie University, Halifax, Nova Scotia \\
\hline 1987 & Alan BR Thomson & University of Alberta, Edmonton, Alberta \\
\hline 1988 & Aubrey Groll & Queen's University, Kingston, Ontario \\
\hline 1989 & lain Cleator & University of British Columbia, Vancouver, BC \\
\hline 1990 & Eldon A Shaffer & University of Calgary, Calgary, Alberta \\
\hline 1991 & Suzanne E Lemire & Université Laval, Quebec, Quebec \\
\hline
\end{tabular}

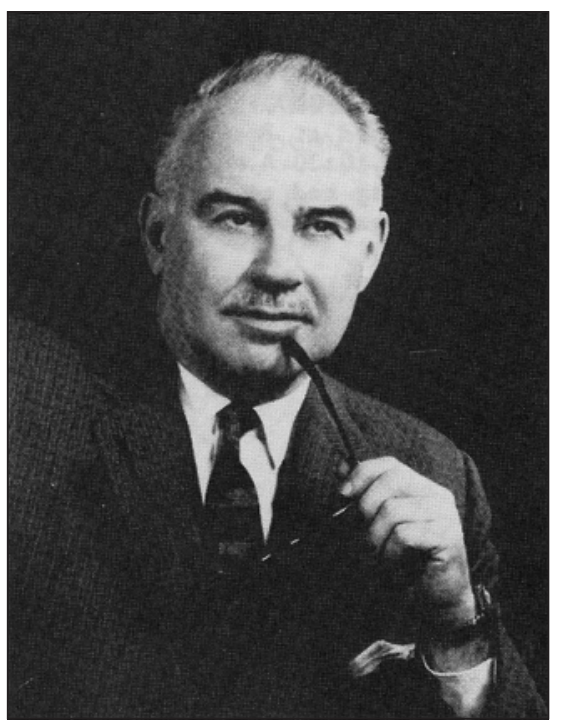

Figure 3) Photograph of Dr Richard D McKenna taken in 1962 at the time of his Presidency. This picture was previously published (2)

State on January 12, 1962; one day later the Chairman, Dr McKenna, submitted the duly signed memorandum of agreement (Figure 1) to the meeting of the temporary Board, and the suggested bylaws and corporation were accepted. A seal was designed by Ivan Beck which depicted the gastrointestinal tract in a stylized form. The drawing was surrounded by the words Canadian Association of Gastroenterology/ L'Association canadienne de gastroentérologie Inc January 12, 1962 (Figure 2). The names of the founding members are shown in Figure 1; the initial members who joined the Association in its first year are listed in Table 4.

Officers of the Canadian

Association of Gastroenterology

The original officers of the Association were the President, immediate Past-President, President-Elect, VicePresident, Secretary and Treasurer. These, with the six councilors (to represent geographic areas, linguistic background and specialty interests) constituted the Board of Directors, officially referred to as the Governing Board. In 1969 the post of Archivist was added to the Board. The names of the presidents and their year of tenure are shown in Table 5. The photograph of Dr McKenna, the first President of the CAG, is shown in Figure 3 and 

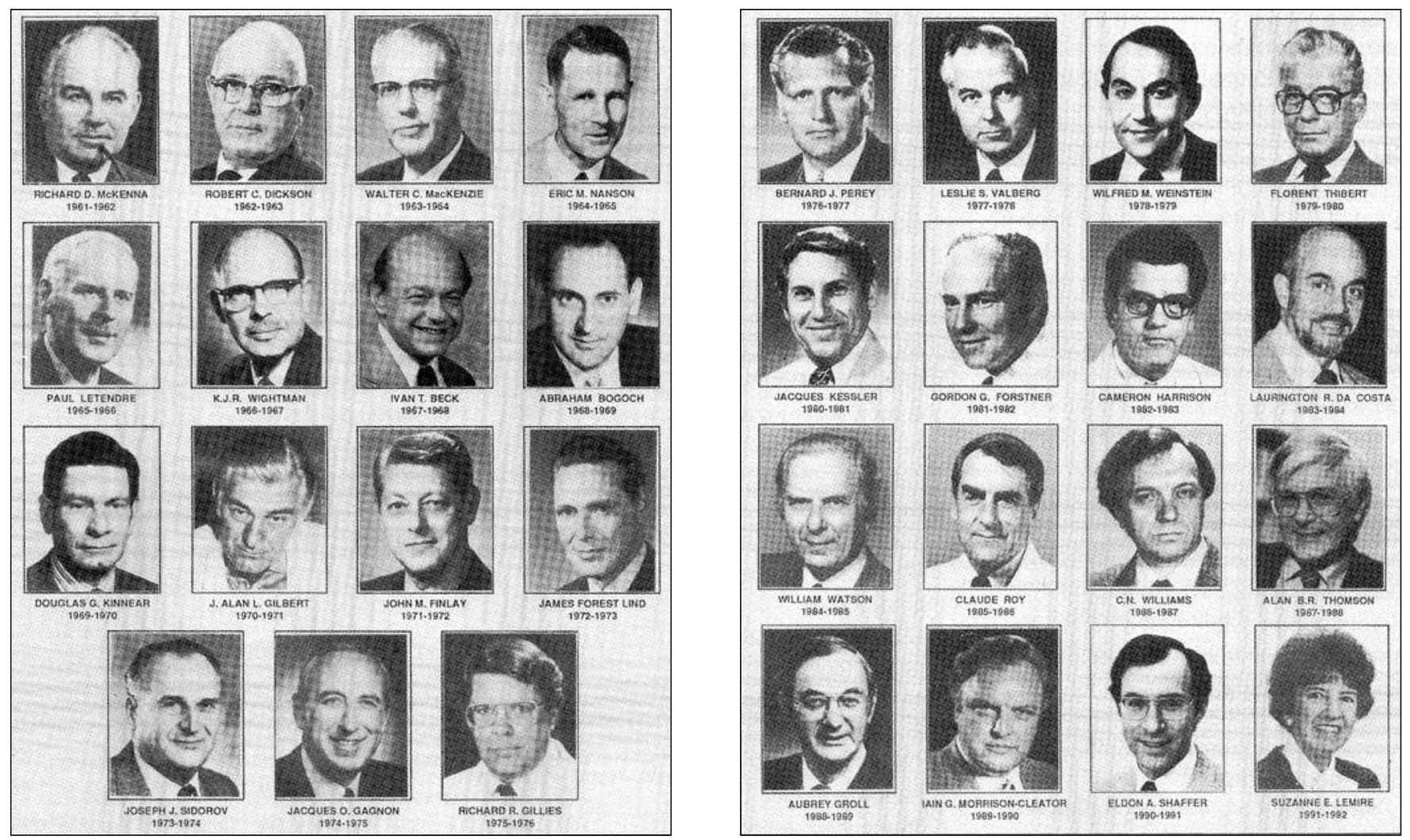

Figure 4) Photos of successive presidents of the Canadian Association of Gastroenterology

photographs of subsequent presidents, taken at the time of their presidency, are shown in Figure 4. The names of secretaries, treasurers and archivists of the Association are shown in Table 6 and those of councilors in Table 7.

The 1987 President, Dr Alan Thomson, suggested that to introduce novel ideas to the Association six 'ad hoc councilors' should be appointed to join the Board. These ad hoc councilors were selected from the younger members of the Association and were expected to participate in the deliberation of the Governing Board but had no votes. It rapidly became clear that these colleagues did not feel entirely at home on the Board and that they did not contribute as much as they could, mainly because of their limited understanding of the Association; most of them subsequently were appointed to another committee to become acquainted with the ongoing issues of the CAG. This did not turn out to be a success (see section on relation of the Board and membership) and, therefore, the issue of ad hoc councilors is being reviewed. At the January 1992 meeting it was suggested that councilors should be appointed by regions to facilitate a more important local input from the membership to the Board. This suggestion is being reviewed and will be presented to the membership.

\section{Membership}

The original membership rulings were strict. Election to 'active membership' was open to physicians, surgeons and scientists who had attained eminence in their work in subjects pertaining to the digestive system. 'Associate members' had to possess such qualifications as to give promise of advancement to active membership. Associate members could not hold office and could not vote. Active members at the age of 65 years could be made 'senior members' on request. 'Honorary members' were physicians, surgeons and scientists who had attained pre-eminence in gastroenterology and metabolism. A list of honorary members is given in $\mathrm{Ta}$ ble 8. In 1974 the associate membership was dropped, abolishing the double standard of membership. Candidates for active membership were requested to have demonstrated active involvement (rather than eminence) in areas related to gastroenterology. At the same time 'student membership' was established for residents, fellows and graduate students.

\section{Committees}

A summary of the committees of the CAG is presented in Table 9. The original standing committees were the Nominating Committee, Admissions Committee and Finance Committee. Several ad hoc committees were established and dissolved according to the needs of the Association.

Nominating Committee: The Nominating Committee consists of the President, Past-President, President-Elect and Secretary. They propose names of the new slate of officers to the Board which then submits these for approval to the general membership. Recently it was questioned whether this method of nomination to the Board leads to inbreeding; several steps have been taken to overcome this, such as inclusion of ad hoc councilors to the Board and this year's proposal of regional councilors. It 
TABLE 6

Secretaries, Treasurers and Archivists of the Canadian Association of Gastroenterology

\begin{tabular}{|c|c|}
\hline \multicolumn{2}{|l|}{ Secretaries } \\
\hline Ivan T Beck (Montreal) & $1961-65$ \\
\hline John M Finlay (Toronto) & $1965-69$ \\
\hline Richard R Gillies (Ottawa) & $1969-73$ \\
\hline Ralph E Warren (Toronto) & $1973-77$ \\
\hline $\begin{array}{l}\text { Laurington R DaCosta } \\
\text { (Kingston) }\end{array}$ & $1977-81$ \\
\hline Michael Lichter (Montreal) & $1981-86$ \\
\hline David Lloyd (London) & $1986-88$ \\
\hline James A Barrowman (St John's & $1988-90$ \\
\hline $\begin{array}{l}\text { Richard N Fedorak } \\
\text { (Edmonton) }\end{array}$ & 1990-present \\
\hline \multicolumn{2}{|l|}{ Treasurers } \\
\hline Douglas G Kinnear (Montreal) & $1961-67$ \\
\hline Douglas L Thomson (Montreal) & $1967-70$ \\
\hline Florent Thibert (Montreal) & $1970-77$ \\
\hline Isadore W Weintrub (Montreal) & $1977-81$ \\
\hline $\begin{array}{l}\text { Andre P Archambault } \\
\text { (Montreal) }\end{array}$ & $1981-85$ \\
\hline Alvin Newman (Toronto) & $1985-89$ \\
\hline $\begin{array}{l}\text { Lawrence J Worobetz } \\
\text { (Saskatoon) }\end{array}$ & 1989-present \\
\hline \multicolumn{2}{|l|}{ Archivists } \\
\hline Richard D McKenna (Montreal) & $1969-7 \mid$ \\
\hline Douglas J Buchan (Saskatoon) & $197 \mid-80$ \\
\hline Dr Ivan T Beck (Kingston) & 1980-present \\
\hline
\end{tabular}

was also discussed whether the Nominating Committee should not be expanded to include members at large.

Admissions Committee: The Admissions Committee is responsible for recommending membership criteria and to review the yearly membership applications (chairmen of this committee are listed in Table 10). It is this committee which, under the chairmanship of Dr Richard Hamilton, suggested the abolition of the associate membership and the introduction of the student membership.

Finance Committee: The Finance Committee has become one of the most important instruments of the Association (for chairmen see Table 11). At first it only served to advise the CAG on the financial placement of its funds and propose a budget for the upcoming year. Since the chairmanship of $\mathrm{Dr} \mathrm{Su}$ zanne Lemire, the Committee was made responsible for obtaining support from pharmaceutical companies for the educational aspects of meetings, re-
TABLE 7

Councilors and Ad Hoc Councilors of the Board

\begin{tabular}{|c|c|c|c|}
\hline Bogoch, Abraham & $1961-64$ & Kepkay, David L & $1977-80$ \\
\hline Brown, Malcolm G & $196 \mid-63$ & Lukie, Bryan E & $1977-80$ \\
\hline Letendre, Paul & $1961-62$ & Diamant, Nicholas E & $1980-81$ \\
\hline MacDonald, Robert M & $1961-62$ & Groll, Aubrey & $1980-81$ \\
\hline Nanson, Eric & $1961-62$ & Shaffer, Eldon A & $1980-82$ \\
\hline Wightman, Keith J Roy & $1961-64$ & Beaudin, David J & $1981-83$ \\
\hline Harrison, R Cameron & $1963-65$ & Ste Marie, Micheline T & $1981-83$ \\
\hline Kippen, Duncan L & $1963-67$ & Williams, C Noel & $1981-83$ \\
\hline McKenna, Richard D & $1963-67$ & Blendis, Laurence & $1982-84$ \\
\hline O'Sullivan, Paul M & $1964-65$ & Deneault, Jocelyn J & $1982-84$ \\
\hline Dugal, Jean-Paul & $1964-67$ & Hamilton, J Richard & $1983-85$ \\
\hline McKenzie, Allan D & $1965-67$ & Baker, Selwyn & $1984-86$ \\
\hline Gilbert, J Alan L & $1966-68$ & Cleator, lain G & $1984-86$ \\
\hline Sidorov, Joseph J & $1966-71$ & Kinnear, Douglas $G$ & $1984-86$ \\
\hline Buchan, Douglas J & $1968-70$ & Barrowman, James A & $1985-87$ \\
\hline Gagnon, Jacques & $1968-69$ & Heathcote, Jenny & $1985-87$ \\
\hline Lind, James & $1968-69$ & Gall, Grant D & $1986-88$ \\
\hline McPhedran, Norman T & $1968-70$ & Cohen, Max M & $1987-88$ \\
\hline Gillies, Richard R & $1969-70$ & Clermont, Richard & $1987-89$ \\
\hline McCorriston, James R & $1969-71$ & Sullivan, Stephen N & $1987-89$ \\
\hline Thibert, Florent & $1970-71$ & Danzinger, Rudolph & $1988-90$ \\
\hline Lacerte, Marcel & $1970-72$ & Depew, William T & $1988-90$ \\
\hline Hildes, John A & $1971-71$ & Lahaie, Raymond G & $1989-90$ \\
\hline Sherbaniuk, Richard W & $1971-73$ & MacSween, Miller H & $1989-90$ \\
\hline Kinnear, Douglas G & $1972-73$ & Chaun, Hugh & $1990-92$ \\
\hline Valberg, Leslie S & $1972-74$ & Sutherland, Lloyd R & $1990-92$ \\
\hline Perey, Bernard & $1972-74$ & Bourdages, Raymond & $1990-93$ \\
\hline MacDonald, Walter C & $1972-74$ & Keith, Roger & $1990-93$ \\
\hline Hamilton, John D & $1973-75$ & Scully, Linda J & $1991-94$ \\
\hline Potvin, Laurent & $1973-75$ & Cockeram, Alan W & $1991-94$ \\
\hline Weinstein, Wilfred $M$ & $1974-76$ & Ad Hoc Councilors & \\
\hline Harrison, Cameron & $1975-76$ & Goodacre, Robert L & $1989-92$ \\
\hline Roy, Claude C & $1975-76$ & Paterson, William G & $1988-91$ \\
\hline Thompson, W Grant & $1975-76$ & Reynolds, Richard P & $1988-91$ \\
\hline Gagnon, Jacques Omer & $1975-79$ & Pare, Pierre & $1988-91$ \\
\hline Watson, William C & $1976-79$ & Lam, Edwin & $1988-91$ \\
\hline Badley, Bernard & $1977-79$ & Yacyshyn, Bruce R & $1988-91$ \\
\hline Devroede, Ghislain & $1977-80$ & & \\
\hline
\end{tabular}

search fellowship and, in 1989, for funds required for the Association's bid for the World Congress of Gastroenterology. This committee has done an excellent job in organizing the financial aspects of the Association and providing guidance to the Treasurer.

Because of the Finance Committee's frequent interactions with the pharmaceutical industry, in 1991 Dr Malcolm C Champion was appointed Chairman of the Industry Relations Committee, a subcommittee of the Finance Committee, and asked to review (in conjunction with the Ethics Committee) the methods by which conflict of interest between the CAG and different members of the pharmaceutical industry could be avoided. Their report has now been submitted and clearly stated that meetings can obtain CAG support and officially be accepted as a CAG sponsored event only if the meeting was fully organized by the CAG without input from the pharmaceutical industry. Having submitted this report, the Industry Relations Committee has now been dissolved. Any CAG supported event has to be approved by the Chairman of the Education Committee, have the finances reviewed by the Fi- 
nance Committee and be accepted by the Board.

Program Committee: The Program Committee was made responsible for organization of the scientific, business and social aspects of the annual meetings. In the first years, when the Association held its assembly together with that of the CMA, this committee had little to do, as there was only a one-day scientific meeting and a combined social and business lunch. The task of the Program Committee became more demanding once the CAG meeting was moved to coincide with that of the RCPSC. Coordination with the RCPSC, the Canadian Society for Clinical Investigation (CSCI) and other national societies became necessary both at the scientific and social levels. Between 1977 and 1984, Dr Laurington $\mathrm{R}$ (Larry) DaCosta played a major role in achieving better cooperation with other societies and in the reorganization of the annual meeting, first as secretary and then as president. Presently a standing committee exists, consisting of the CAG President (Chairman), Past-President, Secretary, Chairman of the Local Arrangement Committee, the Research Committee and the Education Committee. In addition, there are appointed readers to judge the anonymously submitted abstracts. In recent years the organization of the program has become a major problem, because in addition to interactions with other societies, the CAG tried to satisfy its many constituents: gastroenterologists, surgeons, other clinicians in private practice, clinical teachers as well as clinical investigators and basic scientists. A major change occurred in 1992, when on the request of Dr John Wallace, Chairman of the Research Committee, the Board agreed that abstracts be read and judged by the Research Committee. Time will tell whether this will lead to a better selection of abstracts.

Local Organizing Committee: The Local Organizing Committee consists of prominent gastroenterologists of the city where the annual meeting is held. They are responsible for finding the appropriate location for the scientific and business meetings, arranging the social
TABLE 8

List of Honorary Members

\begin{tabular}{l}
\hline Dr Charles H Best \\
Toronto, Ontario* \\
Dr Henry L Bockus \\
Philadelphia, Pennsylvania, USA* \\
Dr Charles F Code \\
Rochester, Minnesota, USA \\
Dr Robert Clark Dickson \\
Halifax, Nova Scotia* \\
Dr Eric M Nanson \\
Saskatoon, Saskatoon * \\
Dr Morton I Grossman \\
Los Angeles, California, USA* \\
Dr Franz J inglefinger \\
Boston, Massachusetts, USA* \\
Sir Francis Avery Jones \\
London, United Kingdom \\
Dr Paul Letendre \\
Montreal, Quebec* \\
Dr Ernest J Maltby \\
Toronto, Ontario* \\
Dr G Gordon McHardy \\
New Orleans, Louisiana, USA \\
Dr Walter C MacKenzie \\
Edmonton, Alberta* \\
Dr H Rocke Robertson \\
Montreal, Quebec \\
Dr Douglas L Thomson \\
Montreal, Quebec* \\
Dr Clarence J Tidmarsh \\
Montreal, Quebec* \\
Dr DR Webster \\
Montreal, Quebec* \\
Dr Keith J Roy Wightman \\
Toronto, Ontario* \\
*Deceased \\
\end{tabular}

events, and organizing and printing the program.

Postgraduate and Education Committees: Throughout the years, five different committees dealt with postgraduate and continuing medical education (chairmen are presented in Table 12). The Postgraduate Education Committee, established in 1962, reports on the status of postgraduate training in Canada and recommends methods to be adopted for postgraduate training in gastroenterology. In 1967 the CAG officially requested the RCPSC to establish gastroenterology as one of the recognized subspecialities of internal medicine. A request for the recognition of the specialty of pediatric gastroenterology was made at a later date. In 1968 the RCPSC established a Specialty Committee in Gastroenterology (members are presented in Table 13). In May
TABLE 9

Committees of the Canadian Association of Gastroenterology

\begin{tabular}{l} 
Standing Committees \\
Nominating Committee \\
Admissions Committee \\
Finance Committee \\
Ad Hoc Committees \\
Program Committee \\
Local Organizing Committees \\
Committees dealing with Post Graduate \\
and Continuing Medical Education \\
Post Graduate Education Committee \\
Training and Education Committee \\
Royal College of Physicians and \\
Surgeons Specialty Committee in \\
Gastroenterology \\
Program Directors Committee \\
Education Committee \\
Research Committee \\
Endoscopy Committee \\
International Liaison Committee \\
Ethics Committee \\
Industry Relations Committee \\
Advisory Committee On Manpower \\
Royal College of Physicians and \\
Surgeons/Canadian Medical \\
Association Maintenance of \\
Competence Committee \\
\hline
\end{tabular}

TABLE 10

Chairmen of the Admissions Committee

\begin{tabular}{lc}
\hline Kippen, Duncan L (Winnipeg) & $1961-64$ \\
Ballem, C Miller (Montreal) & $1964-65$ \\
Gilbert, J Alan L (Edmonton) & $1965-67$ \\
Lind, James F (Winnipeg) & $1967-68$ \\
O'Sullivan, Paul M (Toronto) & $1968-69$ \\
Bingham, John R (Toronto) & $1969-7 \mid$ \\
Prokipchuk, Edward J & \\
$\quad$ (Toronto) & $1971-72$ \\
Hamilton, John R (Toronto) & $1972-73$ \\
Badley, Bernard WD (Halifax) & $1973-76$ \\
Lacerte, Marcel (Quebec) & $1976-77$ \\
Baillargeon, Jacques & \\
$\quad$ (Montreal) & $1977-79$ \\
Deneault, Jocelyn J (Ottawa) & $1979-81$ \\
Ghent, Cameron N (London) & $1981-83$ \\
Beaudin, David J (St John's) & $1983-84$ \\
Danzinger, Rudolph G & \\
$\quad$ (Winnipeg) & $1984-85$ \\
Gall, D Grant (Calgary) & $1985-86$ \\
Scott, Gerald W (Edmonton) & $1986-87$ \\
Haddad, Henry (Sherbrooke) & $1987-88$ \\
Leddin, Desmond J (Halifax) & $1988-91$ \\
Goodacre, Robert L (Hamilton) & $1991-92$ \\
\hline
\end{tabular}


TABLE 11

\section{Chairmen of the Finance Committee}

\begin{tabular}{ll}
\hline Kinnear, Douglas G (Montreal) & $1967-68$ \\
Thomson, Douglas L (Montreal) & $1968-69$ \\
Beck, Ivan T (Kingston) & $1969-73$ \\
Lacerte, Marcel (Quebec) & $1973-74$ \\
Crispin, John S (Winnipeg) & $1974-75$ \\
Weintrub, Isadore W (Montreal) & $1975-77$ \\
Anderson, Frank H (Vancouver) & $1977-79$ \\
Mishkin, Seymour (Montreal) & $1979-81$ \\
Shaffer, Eldon A (Calgary) & $1981-82$ \\
Blendis, Laurence M (Toronto) & $1982-83$ \\
Lemire, Suzanne E (Quebec) & $1983-90$ \\
Champion, Malcolm C & \\
$\quad$ (Ottawa) & $1990-93$ \\
Chairmen of the Ad Hoc Industry & \\
Relation Committee & \\
Champion, Malcolm C & \\
$\quad$ (Ottawa) & $1991-92$ \\
\hline
\end{tabular}

1968, the Postgraduate Education Committee of the CAG held a joint meeting with the Specialty Committee of the Royal College. These committees established some of the salient points of the training requirements and the methods of examination in gastroenterology. In view of the new issues to be dealt with in postgraduate education, on the recommendation of $\mathrm{Dr}$ Doug Kinnear, in 1969 the Postgraduate Education Committee was renamed as the Training and Education Committee. The terms of reference of this committee were to deal with standards for Royal College Fellowships in gastroenterology, selection of examiners and accreditation of training programs. In 1971 this committee, chaired by Dr Joe Sidorov, submitted its report on the desirable attributes of a gastroenterologist and on the requirements for accreditation of training programs.

The first Royal College examination in gastroenterology was held in 1971. (Examination Board members from 1971 to 1992 are listed in Table 14). The experience of the first years of this examination was reviewed by $\mathrm{Dr}$ Sidorov (3). Once the college accepted gastroenterology as a specialty, the final decision making shifted from the Training and Education Committee to the Royal College Specialty Committee. Therefore, in 1973, the CAG decided that the Chairman of the Royal
TABLE 12

Chairmen of Committees dealing with Postgraduate and Continuing Medical Education

\begin{tabular}{|c|c|}
\hline \multicolumn{2}{|c|}{ Postgraduate Education Committee } \\
\hline Kinnear, Douglas G (Montreal) & $1963-68$ \\
\hline $\begin{array}{l}\text { McKenna, Richard D } \\
\text { (Montreal) }\end{array}$ & $1968-69$ \\
\hline \multicolumn{2}{|c|}{ Training and Education Committee ${ }^{\dagger}$} \\
\hline Sidorov, Joseph E (Halifax) & $1969-72$ \\
\hline Gilbert, J Alan L (Edmonton) & $1972-74$ \\
\hline \multicolumn{2}{|c|}{$\begin{array}{l}\text { Royal College Specialty Committee in } \\
\text { Gastroenterology }\end{array}$} \\
\hline Gilbert, J Alan L (Edmonton) & $1970-74$ \\
\hline Gillies, Richard R (Ottawa) & $1974-82$ \\
\hline Thibert, Florent (Montreal) & $1982-86$ \\
\hline $\begin{array}{l}\text { DaCosta, Laurington } \mathrm{R} \\
\text { (Kingston) }\end{array}$ & 6-present \\
\hline \multicolumn{2}{|l|}{ Program Directors Committee ${ }^{\ddagger}$} \\
\hline Watson, William C (London) & $1974-82$ \\
\hline Thibert, Florent (Montreal) & $1982-86$ \\
\hline $\begin{array}{l}\text { DaCosta, Laurington } \mathrm{R} \\
\text { (Kingston) }\end{array}$ & $1986-87$ \\
\hline Beck, Ivan $T$ (Kingston) & $1987-89$ \\
\hline $\begin{array}{l}\text { Sutherland, Lloyd } \\
\text { (Calgary) }\end{array}$ & present \\
\hline \multicolumn{2}{|l|}{ Education Committee } \\
\hline Shaffer, Eldon A (Calgary) & $1985-89$ \\
\hline $\begin{array}{l}\text { Connon, Joseph J } \\
\text { (Toronto) }\end{array}$ & 9-present \\
\hline \multicolumn{2}{|c|}{$\begin{array}{l}\text { Canadian Association of Gastroenterology } \\
\text { Representative to Royal College of Physi- } \\
\text { cians and Surgeons of Canada/Canadian } \\
\text { Medical Association Maintenance of } \\
\text { Competence Committee }\end{array}$} \\
\hline van Rosendaal, Guido & 19 \\
\hline
\end{tabular}

${ }^{*}$ The Postgraduate Education Committee was renamed the Training and Education Committee in 1969 and was given new terms of reference; ${ }^{\dagger} \mathrm{As}$ of 1973 the Chairman of the Royal College Specialty Committee on Gastroenterology (appointed by the College) was 'nominated' by the Canadian Association of Gastroenterology (CAG) as the Chairman of the CAG Training and Education Committee. In 1977 the Training and Education Committee was abolished and the Royal College Specialty Committee replaced this Committee of the CAG. In 1985 the CAG re-established its own Education Committee, and the Chairman of the Royal College stopped being a member of the CAG Board; ${ }^{7} \mathrm{Be}$ tween 1982 and 1986 the Chairman of the Royal College Committee on Gastroenterology acted as the 'Coordinator' of program directors. From 1987 a 'Chairman' of the Program Director's Committee represented the program directors view to the Board

College Specialty Committee in Gastroenterology become automatically the Chairman of the Training and Education Committee of the CAG. This allowed the Chairman of the Royal College Committee to report to the
CAG on examinations, training program approvals, manpower requirements, etc.

To deal with problems related to the running of the individual training programs, a Committee of Program Directors was established in 1974. At the start, with Dr William C (Bill) Watson as its Chairman, this committee acted on its own and provided independent input to the Board. The subsequent Chairman, Dr Florent Thibert, was also Chairman of the Royal College Committee on Gastroenterology. Because every Program Director was also a 'Corresponding Member' of the Royal College Specialty Committee, the annual meetings of the two committees were combined. Thus, sometimes it was difficult to discern whether the Chairman's report to the CAG was that of the Royal College Committee or that of the Committee of Program Directors.

In 1977 the CAG adopted the Royal College Committee in Gastroenterology as the CAG Committee on Training and Education, and the Chairman of the Royal College Committee in Gastroenterology became ex-officio member of the CAG Governing Board. This meant that the same person reported for the CAG Committee on Training and Education, Program Director's Committee and simultaneously represented the Royal College. This led to considerable confusion, and when Dr Larry DaCosta became Chairman of the Committee in 1986 he proposed that the Chairman of the Royal College Committee should not be a member of the CAG. On the basis of this, the Training and Education Committee was dissolved and a separate Chairman was appointed to the Education Committee and the Program Director's Committee. However in spite of, or perhaps because of, the close interactions of these Committees, the CAG had tremendous input in the organization and structuring of postgraduate training in gastroenterology. It is not an exaggeration to state that without the CAG, gastroenterology would not be a subspecialty in Canada.

While the training of gastrointestinal residents was a function of the Committee of the Program Directors 
TABLE 13

Specialty Committee in Gastroenterology: Alphabetical listing of Committee Members. Approved by Council in 1968

\begin{tabular}{|c|c|c|c|c|c|c|c|c|c|}
\hline Name & Chairman & Nucleus & $\begin{array}{l}\text { Corre- } \\
\text { sponding }\end{array}$ & Ex-officio & Name & Chairman & Nucleus & $\begin{array}{l}\text { Corre- } \\
\text { sponding }\end{array}$ & Ex-officio \\
\hline Anderson, $\mathrm{FH}$ & & & $1989-92$ & & Kinnear, DG & & $1968-72$ & $\begin{array}{r}1976-78 \\
1980-88\end{array}$ & $1978-80$ \\
\hline Archambault, AP & & & $1987-88$ & $1984-87$ & Kopelman, $\mathrm{H}$ & & & $1990-92$ & \\
\hline Badley, BWD & & & $1978-80$ & $198 \mid-83$ & Lahaie, RG & & & & $1988-90$ \\
\hline Baillargeon, J & & & $\begin{array}{c}1972-74 \\
1978-80\end{array}$ & & Leddin, D & & & 1991 & \\
\hline Baker, S & & & $1978-84$ & & Levy, G & & & 1991 & \\
\hline Barrowman, JA & & $1987-90$ & $1982-86$ & & Lloyd, DA & & & $1987-88$ & \\
\hline Beaudry, R & & & $\begin{array}{c}1976-78 \\
1982-84\end{array}$ & $1978-80$ & MacDonald, WC & & $1976-80$ & $1982-85$ & \\
\hline Beck, IT & & $1968-72$ & $1976-86$ & & Martin, F & & $1980-82$ & $1982-86$ & \\
\hline Bogoch, A & & & $1976-78$ & & McHattie, JD & & 1989-92 & & \\
\hline Bondy, DC & & & $1976-78$ & & Menard, D & & $1987-92$ & & $1992-94$ \\
\hline Chew, CK & & & $1976-78$ & & Pichette, LP & & $1968-72$ & & \\
\hline Connon, JJ & & & $1978-84$ & & Prokipchuk, EJ & & & $1976-78$ & \\
\hline DaCosta, LR & $1987-90$ & $1982-86$ & 1992 & $1990-92$ & Reynolds, RPE & & & $1990-92$ & \\
\hline Depew, W & & & $1989-92$ & & Roy, C & & $\begin{array}{c}1974-76 \\
1983-86\end{array}$ & $1989-90$ & \\
\hline Diamant, NR & & & $1976-78$ & & Sainte-Marie, M & & $1987-92$ & & \\
\hline Durie, PR & & & $1989-92$ & & Scott, RB & & $1976-80$ & $1989-92$ & \\
\hline Finlay, J & & $1972-76$ & & & Seaton, $T$ & & & $1978-82$ & \\
\hline Forstner, GC & & & $1972-74$ & & Shaffer, EA & & $1982-86$ & & \\
\hline Gall, DG & & $1976-80$ & $1989-90$ & & Sherbaniuk, RW & & $1968-74$ & & \\
\hline Gilbert, JAL & $1968-74$ & & & & Shipman, RT & & $1980-82$ & & \\
\hline Gillies, RR & $1974-82$ & $1972-74$ & & & Sidorov, J & & $1970-76$ & & $1974-76$ \\
\hline Giroux, Y & & & & $1980-83$ & Steinbrecher, U & & & 1986-89 & \\
\hline Goodacre, R & & & 1989-92 & & Sullivan, SN & & & $1989-90$ & \\
\hline Goresky, C & & & 1989-92 & & Sutherland, LR & $199 \mid-92$ & $1987-90$ & & \\
\hline Groll, A & & & $1972-74$ & & Thibert, F & $1982-86$ & $1972-76$ & $1975-77$ & \\
\hline Haddad, H & & & $1985-88$ & & Thompson, WG & & & $\begin{array}{c}1980-84 \\
1987-92\end{array}$ & $1984-86$ \\
\hline Hamilton, JR & & $1974-76$ & $1976-78$ & & Thomson, ABR & & & $1982-92$ & $1987-89$ \\
\hline Heathcote, EJL & & $199 \mid-92$ & & & Villeneuve, J-P & & & $199 \mid-92$ & \\
\hline Hershfield, NB & & $1978-82$ & & & Watson, WC & & $1978-82$ & $\begin{array}{c}1976-78 \\
1982-86\end{array}$ & \\
\hline Hunt, R & & & $1982-88$ & & Wensel, RH & & $1974-78$ & 1978-82 & \\
\hline Jeejeebhoy, $\mathrm{K}$ & & & $\begin{array}{c}1972-76 \\
1989-92\end{array}$ & & Whittaker, JS & & 199|-92 & & \\
\hline Kepkay, DL & & & $1978-80$ & & Williams, CN & & $1982-86$ & $199 \mid-92$ & \\
\hline Kessler, JL & & & $\begin{array}{c}1972-74 \\
1976-82\end{array}$ & & Worobetz, LJ & & $1985-88$ & & \\
\hline
\end{tabular}

and of the Royal College Specialty Committee in Gastroenterology, neither of these committees dealt with continuing medical education. In the spring of 1985 a new committee, the Education Committee, was established to deal mainly with continuing medical education and to organize the educational aspects of the annual meeting. Research Committee: The Research Committee was established in 1969 with Dr James Lind as its first chairman (chairmen are listed in Table 15). Responsibilities of this committee included examining the year-to-year status of gastrointestinal research in Canada and coordinating with fundraising agencies. Later this committee was directed to review and adjudicate the two student research prizes (one established by the CAG and the other by the Canadian Foundation for Ileitis and
Colitis [CFIC]), the applications for the two Research Fellowships (supported by Merck Frosst Canada Inc and Janssen Pharmaceutica) and, recently, the Summer Student Award (supported by SmithKline Beecham). The committee is responsible for organization of research symposia and research workshops at the CAG annual meeting. Endoscopy Committee: An Endoscopy Committee was initiated in May 1973 
TABLE 14

Royal College of Physicians and Surgeons of Canada Examiners in Gastroenterot ogy since 1971

\begin{tabular}{|c|c|c|c|}
\hline \multicolumn{2}{|l|}{ English board } & Thompson, William G & $1981-83,{ }^{\prime} 84-86^{\star}$ \\
\hline Badley, Bernard & $1975-80,{ }^{\prime} 81-83^{*}$ & Thomson, Alan BR & $1981-86,{ }^{\prime} 87-89^{*}$ \\
\hline Beck, Ivan T & $1977-84$ & Valberg, Leslie S & 1974 \\
\hline Dacosta, Laurington $\mathrm{R}$ & $1985-89, ' 90-92^{*}$ & Williams, Christoper & $1987-90$ \\
\hline Finlay, John M & $71,{ }^{\prime} 72-74^{\star}, 75-77$ & French Board & \\
\hline Gilbert, James AL & $1971-74$ & Archambault, AP 1 & $1975-77, ' 78-80, ' 81-83^{\star}$ \\
\hline Heathcote, Elizabeth JL & $1984-89$ & Beaudry, Rene & $1975-77,78-80^{\star}$ \\
\hline Jabbari, Mansour & $1984-87$ & Beck, Ivan T & $1978-84$ \\
\hline Jeejeebhoy, KN & $1971-74$ & Boivin, Michel & $1991-92$ \\
\hline Kessler, Jacques & $1973-78$ & Giroux, Yvon & $1978-80,{ }^{\prime} 81-83^{*}$ \\
\hline Kinnear, Douglas G & $1977,78-80^{\star}$ & Jabbari, Mansour & $1985-87$ \\
\hline Lahaie, Raymond G & 1987 & Jobin, Gilles & $1988-92$ \\
\hline Lloyd, David A & $1985-87$ & Lahaie, Raymond G & $1987, ' 88-90^{*}$ \\
\hline MacDonald, Walter C & $1976-80$ & Martin, Francois & 1990 \\
\hline Moore, Terrence L & $1989-92$ & Menard, Daniel B & $1987-91, ' 92-94^{*}$ \\
\hline Patel, Dilip G & $1988-92$ & Meunier, Pierre & $1984-86$ \\
\hline Poleski, Martin Henry & $1991-92$ & Pare, Pierre & $1986-92$ \\
\hline Prokipchuk, Edward J & $1978-84$ & Philippon, Fernand & $1971-74$ \\
\hline Sherbaniuk, Richard W & $1971-74$ & Thibert, Florent & $1971, ' 72-77^{\star}$ \\
\hline Sidorov, Joseph J & $1971-73,74-77^{\star}$ & Pediatric Board & \\
\hline Steinbrecher, Urs & $1990-92$ & Kopelman, Hinda & $1991-92$ \\
\hline Stone, RM & 1971 & Sherman, Philip & $1990-92$ \\
\hline Sutherland, Lloyd R & $1988-92$ & Ste-marie, Micheline & $1991-92$ \\
\hline
\end{tabular}

* Chairman of the board

\section{TABLE 15}

Chairmen of the Research

Committee

\begin{tabular}{lc}
\hline Lind, James F (Winnipeg) & $1969-72$ \\
Preshaw, Roy M (Toronto) & $1972-74$ \\
Jeejeebhoy, Khursheed N & \\
$\quad$ (Toronto) & $1974-79$ \\
Forstner, Gordon G (Toronto) & $1979-82$ \\
Thomson, Alan BR (Edmonton) & $1982-85$ \\
Freeman, Hugh J (Vancouver) & $1985-86$ \\
Collins, Steven M (Hamilton) & $1986-89$ \\
Depew, William T (Kingston) & $1989-91$ \\
Wallace, John L (Calgary) & $1991-93$ \\
Chairman of the Ethics Committee \\
Sidorov, J Joseph (Halifax) & $1989-92$ \\
\hline
\end{tabular}

TABLE 16

Chairmen of the Endoscopy Committee

\begin{tabular}{ll}
\hline Beck, Ivan T (Kingston) & $1971-73$ \\
Beck, Ivan T (Kingston) & $1974-78$ \\
Wensel, Ronald H (Edmonton) & $1979-81$ \\
Archambault, Andre P & \\
$\quad$ (Montreal) & $1981-83$ \\
Badley, Bernard WD (Halifax) & $1983-84$ \\
Groll, Aubrey (Kingston) & $1984-85$ \\
Cleator, lain (Vancouver) & $1985-86$ \\
Clermont, Richard J (Montreal) & $1986-87$ \\
Connon, Joseph J (Toronto) & $1987-88$ \\
Marcon, Norman E (Toronto) & $1988-91$ \\
Bailey, Robert J (Alberta) & $1991-93$ \\
\hline
\end{tabular}

TABLE 17

Chairmen of International Liaison Committees

\begin{tabular}{|c|c|c|c|}
\hline \multicolumn{2}{|l|}{ Foreign Relations Secretary } & \multicolumn{2}{|l|}{ International Liaison Secretary } \\
\hline Beck, Ivan T (Montreal) & $1962-65$ & Watson, William C (London) & $1983-86$ \\
\hline Finlay, John M (Toronto) & $1965-69$ & Newman, Alvin (Toronto) & $1986-87$ \\
\hline Gillies, Richard R (Ottawa) & $1969-73$ & Hunt, Richard H (Hamilton) & $1987-90$ \\
\hline \multicolumn{2}{|c|}{ International Liaison Relations Committee } & Sutherland, Lloyd (Calgary) & $1991-94$ \\
\hline Gilbert, J Alan L (Edmonton) & $1973-77$ & \multicolumn{2}{|c|}{$\begin{array}{l}\text { Chairmen of Committees for bids for the } \\
\text { World Congress }\end{array}$} \\
\hline \multicolumn{2}{|c|}{ Liaison Representative to OMGE } & Watson, William C (London) & $1982^{*}$ \\
\hline \multirow[t]{2}{*}{ Watson, William C (London) } & $1981-83$ & Watson, William C (London) & $1986^{\dagger}$ \\
\hline & & Thomson, Alan BR (Edmonton) & $1990^{\ddagger}$ \\
\hline
\end{tabular}

OMGE Organisation Mondiale de Gastroenterologie - World Organization of Gastroenterology. *For 1986 Congress; ' ${ }^{\dagger}$ For 1990 Congress; ${ }^{ \pm}$For 1994 Congress (chairmen are presented in Table 16). The first terms of reference were to represent the CAG in the World Organization of Digestive Endoscopy (Organization Mondiale d'Endoscopie Digestive [OMED]). The committee was reactivated with Dr Ivan Beck as its Chairman in 1974. It was to report on guidelines for the training of gastrointestinal endoscopists and to suggest criteria for minimal facilities necessary for safe endoscopic practice. This report was used as the basis for training requirements in gastroenterology and was sent to the Royal College and different provincial licensing bodies. It was published and was made available to hospitals for information (4,5). In 1977 this committee was discontinued, but was re-established in 1979 under the chairmanship of Dr Ronald Wensel. The new committee was to review the guidelines laid down by the first committee and, if necessary, set up new ones. In its final report Dr Wensel did not propose any changes from those laid down by the first committee. In 1985, during the chairmanship of Dr Aubrey Groll, a set of proposed informed consents was prepared. When the Canadian Association of General Surgeons (CAGS) established its own subcommittee on endoscopy, the CAG Committee was directed to coordinate its guidelines with those of the CAGS Committee. Unfortunately, none of the subsequent committee chairmen could achieve this. In her Presidential Address, Dr Lemire asked the incoming chairman of this committee, Dr Robert (Bob) Bailey, to attempt to re-examine this issue with the CAGS to establish joint criteria for medical and surgical endoscopy training. This is becoming even more important at present, because the criteria for training need to be revised in the light of the newly introduced therapeutic procedures. Dr Lloyd Sutherland, Chairman of the Program Director's Committee, has brought before the Board a recent proposal from the RCPSC Specialty Committee on gastroenterology for the minimal requirements for endoscopic training in the specialty of gastroenterology.

International Liaison Committee: The International Liaison Committee 
TABLE 18

Organizing and Advisory Committee for the bid for the 1994 World Congress

Organizing Committee

John Brown (Vancouver)

lain Cleator (Vancouver)

Richard Hunt (Hamilton)

Alan Thomson (Edmonton)

C Noel Williams (Halifax)

Advisory Committee

Selwyn Baker (Winnipeg)

Jim Barrowman (St John's)

Ivan Beck (Kingston)

Laurie Blendis (Toronto)

Malcolm Champion (Ottawa)

Hugh Chaun (Vancouver)

Steve Collins (Hamilton)

Ed Daniel (Hamilton)

Rudy Danzinger (Winnipeg)

Ghislain Devroede (Sherbrooke)

Gordon Forstner (Toronto)

Grant Gall (Calgary)

Carl Goresky (Montreal)

Aubrey Groll (Kingston)

Dick Hamilton (Montreal)

Pierre Huet (Montreal)

Khursh Jeejeebhoy (Toronto)

Bernard Langer (Toronto)

Suzanne Lemire (Quebec)

Gary Levy (Toronto)

Norm Marcon (Toronto)

Francois Martin (Montreal)

Tom McDonald (London)

Dan Menard (Sherbrooke)

Gerry Morris (Kingston)

Pierre Pare (Quebec)

Claude Roy (Montreal)

Eldon Shaffer (Calgary)

Joe Sidorov (Halifax)

Steve Strasberg (Toronto)

Lloyd Sutherland (Calgary)

Bruce Taylor (Toronto)

Grant Thompson (Ottawa)

Larry Worobetz (Saskatoon)

was established in 1973 (chairmen are presented in Table 17). However, in 1962 the CAG became a member of the World Organization of Gastroenterology (Organization Mondiale de Gastroentérologie [OMGE]) and in 1963, of the Asociacion Interamericana de Gastroenterologia (AIGE). At first the secretary of the CAG acted as the Foreign Relations Secretary. With increasing involvement in international affairs, a
TABLE 19

Location of annual meetings 1962-92

\begin{tabular}{|c|c|c|c|}
\hline Winnipeg, Manitoba & June 1962 & Vancouver, BC & January 1978 \\
\hline Toronto, Ontario & June 1963 & Montreal, Quebec & February 1979 \\
\hline Vancouver, BC & June 1964 & Ottawa, Ontario & June 1980 \\
\hline Montreal, Quebec & May 1965 & Toronto, Ontario & September 1981 \\
\hline Edmonton, Alberta & June 1966 & Quebec, Quebec & September 1982 \\
\hline Quebec, Quebec & June 1967 & Calgary, Alberta & September 1983 \\
\hline Toronto, Ontario & January 1968 & Montreal, Quebec & September 1984 \\
\hline Vancouver, BC & January 1969 & Vancouver, $\mathrm{BC}$ & September 1985 \\
\hline Montreal, Quebec & January 1970 & Toronto, Ontario & September 1986 \\
\hline Ottawa, Ontario & January 1971 & Winnipeg, Manitoba & September 1987 \\
\hline Toronto, Ontario & January 1972 & Ottawa, Ontario & September 1988 \\
\hline Edmonton, Alberta & January 1973 & Edmonton, Alberta & September 1989 \\
\hline Montreal, Quebec & January 1974 & Toronto, Ontario & September 1990 \\
\hline Winnipeg, Manitoba & January 1975 & Quebec, Quebec & September 1991 \\
\hline Quebec, Quebec & January 1976 & Ottawa, Ontario & September 1992 \\
\hline Toronto, Ontario & January 1977 & & \\
\hline
\end{tabular}

BC British Columbia

Committee for International Relations was established in 1973 to represent the CAG at the AIGE and the OMGE meetings. Dr William (Bill) Watson, as chairman of this committee from 1981-86, submitted two Canadian bids to hold the World Congress of Gastroenterology in Toronto. Unfortunately both bids were unsuccessful and the Congress was held in Sao Paolo, Brazil in 1986 and in Sydney, Australia in 1990. In 1988 the CAG decided to make another bid to hold the 1994 World Congress in Vancouver. Dr Alan Thomson chaired the committee to organize the bid. He worked indefatigably and organized a strong Working Committee (Table 18), members of which were invited as visiting professors to several countries and thus travelled as 'ambassadors' for the Canadian bid during 1989 and 1990. Unfortunately this bid was also lost and the 1994 Congress will be held in Los Angeles, California. At present the new Chairman of the International Liaison Committee, Dr Lloyd Sutherland, is negotiating with representatives of the World Congress to establish several satellite meetings in Vancouver.

Ethics Committee: The Ethics Committee was established in 1989 with Joe Sidorov as chairman (Table 15). With diminishing support for research from government and the increasing cost of the educational programs of CAG meetings, the CAG - similar to other medical societies - has become dependent on support from the pharmaceutical industry. To ascertain that this does not lead to ethical conflicts, the CAG established an Ethics Committee under the chairmanship of Dr Sidorov to deal with ethical issues concerning the Association. Included in the terms of reference was the relationship of the CAG with the pharmaceutical industry (for the latter, see the deliberations of the Industry Relations Committee). On the suggestion of the Ethics Committee, the 1992 McKenna Memorial Lecturer, Dr Francisco Vilardell from Barcelona, Spain will talk on ethical issues in gastroenterology.

\section{The New Constitution}

Due to the many changes in committee structure, it was decided that a new constitution was needed and that this should be available for the 25 th anniversary of the Association. On the suggestion of Dr DaCosta, Dr Iain Cleator was to obtain legal help and submit a proposal for the new charter. After several revisions by the Board, the new constitution was incorporated under the provisions of Part II of the Corporation's Act, RSC, 1970, C32, as amended. The document deals with the new membership rules and establishes the new terms of reference of the officers and committees. It became the 
TABLE 20

Annual lecturers, the Richard D McKenna lecturers and the Richard D McKenna Memorial lecturers

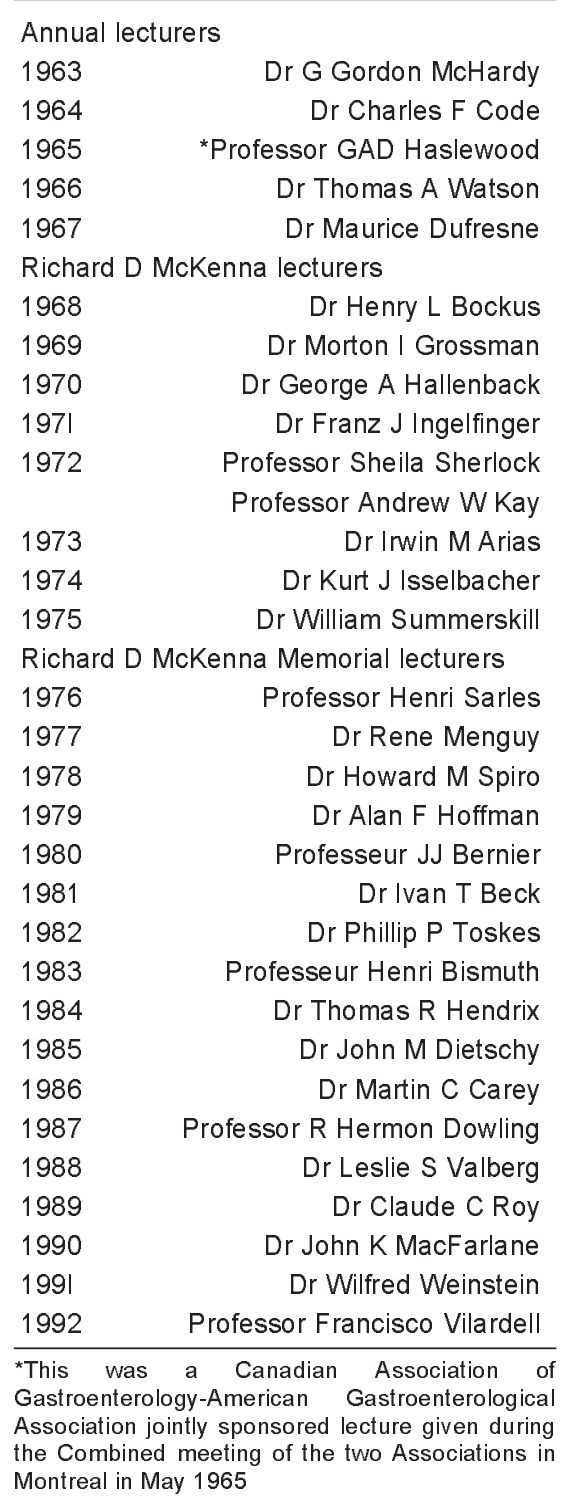

constitution of the Association as of 1986 and is available to our membership in both official languages.

\section{MEETINGS OF THE CANADIAN ASSOCIATION OF GASTROEN - TEROLOGY}

Annual Meetings of the Canadian Association of Gastroenterology

The first scientific meeting was held in conjunction with the Annual Meeting of the CMA at the Fort Garry Hotel in Winnipeg, Manitoba, on June 19,
1962. Subsequent meetings up to 1967 (except for the one in 1965) continued to be held together with that of the CMA. In May 1965 the CAG hosted a joint convention with the American Gastroenterological Association in Montreal. As of January 1968, meetings of the Association were held in conjunction with those of the Royal College of Physicians and Surgeons of Canada and the CSCI. Table 19 shows the location of the meetings from 1962-92. The many changes which occurred in the structure of the program reflected the changing requirements of Canadian gastroenterology. At first, mainly individual papers were presented. As of 1963 there was an annual lecture given by an invited guest ( $\mathrm{Ta}$ ble 20). In 1968 the name of this lecture was changed to the Richard D McKenna Lecture. As the knowledge base in gastroenterology expanded, symposia, courses, workshops and special lectures were added to the program to fulfill the educational and research objectives of the Association. Consequently, the duration of the meetings had to be extended to encourage the submission of the increasing number of Canadian scientific achievements.

Combined sessions with the CSCI, to present individual research papers and a symposium of common interest, were started in 1972. Since 1975, joint symposia were held with the RCPSC, the CSCI, the Canadian Society of Endocrinology, the Canadian Foundation for Diseases of the Liver (CFDL), the Canadian Association for the Study of Liver Diseases (CASL) and several other societies. The first joint symposium with the CAGS was held in 1979.

The concept of a yearly postgraduate course to be held during the CAG meeting was conceived by Larry DaCosta. The first course, Scientific Basis for Therapeutic Decisions in Gastrointestinal Diseases, was organized by $\mathrm{Dr}$ Alan Thomson and was held in September 1984 during Dr Larry DaCosta's presidency. Since that time this oneday course is held annually. It is directed towards the clinical gastroenterologists, but as it is held during the Royal College meeting, many internists and surgeons also attend. Some of these courses were published in a series of books entitled Modern Concepts in Gastroenterology (6-8). A different type of postgraduate course was initiated in 1992 by Drs Alan Thomson and Gary Levy (it was not held during the Annual Meeting of the CAG). This interesting new event is described in some detail in the section on regional and specific meetings.

As of 1985, research workshops were organized to allow for free exchange of ideas among investigators. The first one was organized by Ivan Beck in 1985 on esophageal motility. The speakers were clinicians, biomedical engineers and gastrointestinal technicians. Subsequently, workshops were held in 1988 on the enteric nervous system (organized by Drs Steven Collins and Ed Daniel) and in 1989 on animal models of intestinal inflammation (organized by Dr Collins). The 1990 workshop, put together by Dr Jean Morisset, dealt with the use of cell and tissue culture techniques in gastrointestinal, pancreatic and hepatobiliary research. Drs John Wallace and Mary Perdue arranged for the 1991 workshop on epithelial permeability.

Poster sessions started in 1985 mainly because the symposia, workshops and the course did not allow time for the oral presentations of all the excellent papers submitted. Poster sessions proved to be a great success, providing excellent opportunities for personal interactions among investigators.

The Richard D McKenna Lecture was introduced in 1968. Dr Richard McKenna, the founder and first president of the Association, became ill in 1965 and retired from the active practice of gastroenterology. With the unanimous approval of the membership, in 1968 Dr Beck was instrumental in renaming the annual lecture to the yearly Richard D McKenna Lecture. The first Richard D McKenna lecturer was Dr Henry Bockus, who at that time was one of the most distinguished gastroenterologists of the western world. From then on the yearly Richard D McKenna lecture became the highlight of the annual meetings. The invited lecturers were internationally known 
TABLE 21

Research Lectures

1981 Stephen Robert Bloom, Reader in Medic ine, Royal Postgraduate School of Medic ine, London, England: Newer Aspects of Gut Endoc rinology

1982 Leslie SValberg, MD, Professor of Medic ine, University of Westem Ontario, London, Ontario: State of Iron Absorption and Related Diseases

1983 J ohn Bienenstock, MD, Professor of Medic ine and Pathology, McMaster University, Ha milton, Ontario: The Mucosal Immunologic Network: Its Signific ance in the Physiology of the Intestine

1984 Gordon G Forstner, MD, Professor of Paediatric s and Physiology, University of Toronto, Toronto, Ontario: Pancreatic Insuffic iency: Some Lessons from Cystic Fibrosis

1985 J oseph SDavison, PhD, Professor of Medic al Physiology, Heritage Medical Sc ientist, Dept of Medic al Physiology, Health Sciences Centre, University of Calgary, Calgary, Alberta: The Integration of Gastro intestinal Func tions by the Nervous System

1986 J ean Morisset, PhD, Professor of Biology, Université de Sherbrooke, Sherbrooke, Quebec: The Importance of Gastro intestinal Homones in the Control of Pancreatic Growth and Their Possible Role in the Management of Pancreatic Disea ses

1987 J ohn Brown, PhD, Professor, Dept of Physiology, University of British Columbia, Vancouver, British Columbia: Gastrointestinal Regulation of Insulin Release

1988 Edwin E Daniel, PhD, Professor of Physiology and Pharmacology, McMaster University, Ha milton, Onta rio: GI Motility

1989 Ivan TBeck, MD, PhD, Professor of Medic ine and Physiology, Queen's University, Kingston, Ontario: The Mechanism of the Ethanol-Induced Acute Small Intestinal Injury

1990 Hector Orrego, MD, Professor of Medicine and Pharmacology, University of Toronto, Toronto, Ontario: Alc oholic Liver Disease

199I N Diamant, MD, Professor of Medic ine and Physiology, University of Toronto, Toronto, Ontario: The Vagus and Motoring in the Gut (Because Dr Diamant could not be at the meeting, this lecture will be given in 1992)

1992 Grant D Gall, MD, Professor of Paediatrics, University of Calgary, Calgary, Alberta: Adaptation of the Mucosa to Intestinal Injury
TABLE 22

Titles of symposia co-sponsored by CAG

1969 "The Exocrine Pancreas" organized by Drs Ivan T Beck and Duncan G Sinclair, Queen's University, Kingston, Ontario

1977 "L'Alcool et les Maladies de l'Appareil Digestif' organized by Dr Marcel Lacerte, Laval University, Quebec, Quebec

1986 "Focus on Misoprostil (Prostaglandins)" organized by Dr Alan BR Thomson, Toronto, Ontario

1987 "Workshop on Motility" and "Regional Meeting Gastroenterologists of the Eastern Provinces" organized by Dr Noel Williams, Halifax, Nova Scotia*

1987 The International Course on Therapeutic Endoscopy, organized by Drs Norman E Marcon, Paul Kortan and Gregory Haber, The Wellesley Hospital, University of Toronto, Toronto, Ontario

1988 "Trends in Inflammatory Bowel Disease" organized by Drs LR Sutherland, CN Williams and Francois Martin, Lake Louise, Alberta

1989 "Modern Concepts in Nutritional Support" organized by Drs A Groll and WT Depew, followed by a Postgraduate Course on "Current Issues in Gastroenterology" organized by Drs IT Beck and WT Depew, Queen's University, Kingston, Ontario

1989 "International Course on Therapeutic Endoscopy", organized by Drs Norman Marcon, Paul Kortan, Gregory Haber and Gabor Kandel, The Wellesley Hospital, University of Toronto, Toronto, Ontario

1990 "Trends in Inflammatory Bowel Disease Therapy" organized by Drs L Sutherland, F Martin, R Farmer, G Hellers and N Williams, Halifax, Nova Scotia

1991 "The Fifth International Course on Therapeutic Endoscopy", organized by Drs Norman Marcon, GB Haber, PP Kortan and GP Kandel, The Wellesley Hospital, University of Toronto, Toronto, Ontario

1992 "Consensus Conference on Gastroesophageal Reflux Disease", organized by Drs IT Beck, JJ Connon, S E Lemire and ABR Thomson, Ottawa, Ontario

1992 "Postgraduate Course in Gastroenterology" organized by Drs ABR Thomson and Gary A Levy, Lake Louise, Alberta

1992 "Trends in Inflammatory Bowel Disease Therapy", sponsored by Interfalk Canada Inc and The Canadian Association of Gastroenterology, organized by Drs F Martin, R McLeod, LR Sutherland and CN Williams, SE Lemire, RG Farmer, G Hellers, Quebec, Quebec

*Subsequent Regional Meetings of the Eastern provinces were also cosponsored by the Canadian Association of Gastroenterology investigators and clinical scientists (Table 20). In 1976, after the death of Dr McKenna, the lecture was renamed the Richard D McKenna Memorial Lecture.

The annual research lecture series was proposed in 1981 by Dr Gordon Forstner. The first lecturer was Dr Stephen Robert Bloom from London, England. Although his lecture was a great success, it was decided that - in order to acquaint the membership with work carried out by outstanding Canadian investigators - subsequent lecturers should be Canadians (Table 21).

Student research awards were introduced in 1977 to stimulate gastrointestinal research and to motivate postgraduate trainees to submit their papers to the CAG. Winners of the prize present their papers at the annual meeting. The CAG and the CFIC each established a prize. The first winner of the CAG prize was Dr Arni Sekar (trainee of Dr Grant Thompson, University of Ottawa, Ottawa, Ontario) and of the CFIC prize Ms Jo-Anne Fox ( $\mathrm{PhD}$ candidate from Queen's University, Kingston, Ontario, a student of $\mathrm{Dr}$ Ivan Beck).

The only social event between 1961 and 1971 was a business luncheon, attended by all participants. The first annual dinner was organized in 1972 by Dr John M (Jack) Finlay at the annual meeting in Toronto. The annual dinner has become a treasured tradition of the Association where old friends meet in a relaxed atmosphere.

The printing and organizing of the 
TABLE 23

Visiting research professors

\begin{tabular}{lr}
\hline $\begin{array}{l}\text { Jeejeebhoy, Khursheed N } \\
\text { (Toronto) }\end{array}$ & $198 \mathrm{-}-1982$ \\
Roy, Claude (Montreal) & $1982-1983$ \\
Shaffer, Eldon A (Calgary) & $1983-1984$ \\
Hamilton, Richard J & \\
$\quad$ (Toronto) & $1984-1985$ \\
Hunt, Richard H (Hamilton) & $1986-1987$ \\
Blendis, Laurence M & \\
$\quad$ (Toronto) & $1987-1988$ \\
Barrowman, James A & \\
$\quad$ (St John's) & $1989-1990$ \\
Heathcote, E Jenny L & \\
$\quad$ (Toronto) & $1990-1991$ \\
Williams, Norman (Halifax) & $1991-1992$ \\
\hline
\end{tabular}

Dr Stephen Strasberg was nominated as Visiting Research Professor but could not accept in 198586. No one was appointed in 1988-89

annual program booklet is the duty of the chairman of the Local Organizing Committee. Once the Association started to meet in conjunction with the Royal College, the scientific program of the CAG was published in the RCPSC program. Chairmen of the Local Organizing Committee have often reported that there are major problems with preparing this program, mainly because of the need to coordinate it with that of other societies and the often late release of the final program by the RCPSC. In spite of these difficulties the membership requested that the CAG should continue to print its own program booklet, mainly because a separate program: maintains the identity of the Association; combines all CAG scientific papers, special lectures and symposia, whether they are organized by the CAG alone or in conjunction with other societies; provides the dates and locations of the social and business meetings; contains a list of the current officers of the CAG; and honours previous Presidents and McKenna Lecturers by printing each year a list of all Past-Presidents and McKenna Lecturers.

Regional and specific meetings

These meetings started in 1969 when the CAG, in conjunction with the Medical Research Council and Queen's University, co-sponsored a symposium on the exocrine pancreas
(9). The second symposium was organized by Dr Marcel Lacerte in 1977 at Laval University (Quebec City, Quebec) on "L'alcool et les maladies de l'appareil digestif" (10). As of 1986, after a considerable hiatus, several local and special meetings were sponsored or co-sponsored by the CAG (11-15). For a list of these see Table 22.

One of the new and exciting events which occurred this year was the first CAG Consensus Conference organized by Drs Alan Thomson, Suzanne Lemire, Joe Connon and Ivan Beck. It was held in Ottawa between January 17 to 19, 1992. Gastroesophageal reflux disease was selected as the subject because of the controversies which exist regarding its pathophysiology and treatment. Specific areas of controversy were introduced to the 40 carefully chosen participants by selected speakers, and then discussed in small groups of seven to 12 . The group sessions were summarized by the session chairman and presented for further discussion to the entire group of participants. Agreement was achieved on most issues, and the results of the conference have been publiched in The Canadian Journal of Gastroenterology (16). This conference represents a new beginning in a process of consensus opinions which will be organized on other subjects.

The second novelty introduced this year was a new type of postgraduate course which was held separately from the annual meeting. It was organized by Drs Alan Thomson and Gary Levy, and was held at Lake Louise, Alberta from April 8 to 12, 1992. The purpose of this course was to arrange for close interactions among most gastroenterology trainees and a wide range of faculty. There were up-to-date workshops and plenary sessions given by faculty. The exciting parts of the meeting were the daily sessions where clinical and research trainees gave papers on unusual clinical cases or on their recent research. To ascertain that all trainees could come, they were invited to submit and to present case reports of unusual cases or to present their research work. Thus, they became faculty and their transportation and stay could be supported by generous donations to the CAG by a long list of pharmaceutical manufacturers.

It was a real pleasure to see the quality of submissions and how well they were prepared. The meetings started at 06:30 and finished at 23:00 with the afternoons (13:00 to 17:00) free for skiing, skating etc. However the most important aspect of the free time was achieved by trainee-faculty interaction at a social level. This allowed the trainees of different programs to get to know each other and thus have an opportunity to discuss their various programs. They also could mix easily with faculty of their and other programs. This course, more than the annual meeting held in the umbrage of the large crowds of the Royal College, allowed for most participants to appreciate the strength of Canadian gastroenterology and the CAG.

Visiting research professorships

To improve the visibility of gastrointestinal research in Canada the Research Committee under the chairmanship of Dr Gordon G Forstner proposed the establishment of a Visiting Research Professorship. This post is held by a Canadian researcher who visits the majority of Canadian universities. A list of Visiting Professors is given in Table 23.

\section{ISSUES OF SPECIFIC INTEREST}

\section{Bilingualism}

Maintenance of bilingualism was -and remains - a prime concern of the CAG. The original organizers came from both the French and English community. From the beginning, every effort was made to project a bilingual image. However, the finances of the CAG were never sufficient to have an efficient translating service for all documents. From time to time volunteers (eg, Drs Jacques Gagnon, Marcel Lacerte, Florent Thibert, Andre Archambault and Suzanne Lemire) translated documents and programs. From 1974 to 1985 the program was printed in both languages. Unfortunately, an ongoing accurate translating service 
into French could not be continuously maintained. A major problem for translating the program of the CAG into French was the late release of the final CAG program by the RCPSC office. Therefore on the recommendation of Dr Claude Roy, since 1985 all major events in the program, such as the Richard D McKenna Memorial Lecture, the Research Lecture, the titles of symposia, and all business and social events, are printed in both languages (the titles of papers submitted in English or in French are printed in the language in which they were originally submitted). Several attempts were made to attract members of the Quebec Association of Gastroenterology into the CAG. On the recommendation of Dr Alan Thomson, the 1986 constitution was translated into French, and a major drive to increase membership, with special emphasis on enrolling more French members, was undertaken during the presidency of Dr Claude Roy in 1985. This effort continues.

\section{Examination in gastroenterology}

The first examination in gastroenterology was held in 1971. Of major concern to the program directors was the high failure rate. Dr Leslie Valberg reorganized the examinations by having the examiner observe the candidates during the history and physical examination. This revealed that the major reason for the high failure rate was inadequate preparation of candidates in these areas. The standards of the examinations and their method of conducting them have been reviewed by Joe Sidorov (3).

\section{Relation of the Board and membership}

At the time of the establishment of the Association in 1962, the initial membership of the Association was 51; 11 of these sat on the Board. One year later, with the first past-president on the Board, this number increased to 12 . The initial members and the members who joined within the next few years were all close friends. The Board altered sufficiently rapidly to allow constant change from active member to membership on the Board and vice versa, leading to close and continuous interaction between the membership and the Board.

As the number of the members increased, the Board has appeared to become increasingly isolated, and the Executive has made numerous decisions which were then presented to the membership, sometimes with very little time for discussion at the general meeting. By 1974 Joe Sidorov, in his PastPresident's Report, emphasized the need for better communication between the Board and the membership. He stated that it is essential that the Board be supplied with a list of names of members who were interested and capable of organizational work, and that they should be given the opportunity to contribute to the Association. He also proposed that a list of nominations to the Board should be sent immediately after the semi-annual meeting to all members, asking them to supply additional nominations.

Dr Sidorov considered that the second problem was the lack of communication between the membership and the Board. Because of the pressure of time, the annual business meeting was run very efficiently and economically, yet did not represent a clear picture of what was actually accomplished, nor did it give any opportunity for discussion and criticism by the general membership. Without knowing the extent and the amount of work accomplished by various committees and the Governing Board, the general membership could not appreciate the degree of progress and might feel that not a lot was happening.

Based on his proposal, the business meeting was extended and a major change in the membership of the Board occurred during the next few years. Many of the posts were filled with individuals in their thirties. Among these were Dr Grant Thompson as Councillor, Dr Marcel Lacerte as Chairman of the Finance Committee and Dr Larry $\mathrm{DaCosta}$ as Secretary. Involvement of young people in the workings of the Association was maintained throughout the years, but the younger people of the Board in time became 'establishment' and the Board again started to consist of mainly senior academics. The issue was again raised by Dr Alan Thom- son during his presidency in 1988 , and on his suggestion six younger members were appointed as ad hoc councilors to form a link between the Board and the membership (for details see section on Officers of the Association).

Unfortunately these councilors did not improve communication mainly because, even though they were younger, they were not necessarily representative of the membership at large. Several of our members continued to feel apart from the decisions made by the CAG. This was well-expressed in a 1990 letter by Sam Lee from Calgary, Alberta, in which he wrote "There is a widespread feeling, justified or not, among many of the rank and file CAG members, that the CAG is controlled by an 'old boys' club".

The Board of the CAG took these complaints very seriously. During his presidency, Dr Eldon Shaffer organized a meeting in October 1990 to discuss the strategic plan of the Association and to establish better ways of interaction between the Board and membership. At this meeting it became clear from the discussion that the major problem was that the CAG tries to satisfy many constituents with varying interests. Among these are the practising clinicians of different disciplines, clinical investigators and basic scientists. This mix of membership has a major impact on the program as laboratory scientists are not interested in clinical papers, while some of the practising clinicians are not attracted to the basic science sessions.

A decision was made at the strategic planning meeting to have the beginning of the meeting mainly of interest to clinicians and the second part to satisfy the clinical investigators and basic scientists. Thus, it was decided that the course should always be the first day and that during the second day there should be clinical symposia, clinical papers and posters. In the third and fourth days of the meeting there should be workshops, and basic science papers and posters. This plan, however, may turn out to be very difficult to main- 
TABLE 24

Canadian Association of Gastroenterot ogy strategic plan (1990)

\section{A. MISSION STATEMENT}

Key ingredients: To foster optimal gastrointestinal health for Canadians

B. GOALS:

By promoting:

1) Research into Digestive Disea ses

2) Education

3) High ethic al standards in practice

4) Quality health care delivery

5) Communic ations between members - locally, regionally and at national meetings

6) Increased representation to:

a) govemments

b) the Royal College

c) other organizations

7) The profile of C.A.G. and Canadian Gastroenterologists

\section{OBJECTIVES}

1) To promote research into nomal gastro intestinal function and digestive diseases

2) To enhance professional education

3) To develop standards on ethic al conduct and for bioethics in GI research

4) To promote quality health care delivery for our patients

5) To improve communications between members

6) To increase our representation to Govemment - become proactive in establishing fee standards with provincial govemments - monitor the adequacy of facilities and resources for GI care throughout Canada - inform govemment of deficiencies or excesses

7) To enhance the profile of C.A.G. and Canadian Gastroenterologists

\section{OTHER CONSIDERATIONS}

8) Establish a Digestive Diseases Foundation of Canada with a National Office with an Executive Director to plan and manage the financial affairs of C.A.G. to better coordinate all our efforts

Eldon A Shaffer, MD, FRCPC, FACP

President

Canadian Association of Gastroenterology tain, mainly because the program will have to be correlated with that of the CSCI, the CAGS and the CASL.

On the basis of discussions at the meeting, a strategic plan was proposed; this was published in the July 1, 1991 issue of the Newsletter and presented at the General Membership Meeting. Of interest is that no comments were received regarding the plan either after the circulation of the Newsletter or at the general meeting of the membership. Thus the 1991 Strategic Plan has now been accepted by the CAG. The Plan starts with a Mission Statement, according to which the CAG is to foster optimal gastrointestinal health for Canadians, and continues with its goals and objectives. (The plan is documented in Table 24). Also, under miscellaneous considerations the CAG endorsed the establishment of a Digestive Diseases Foundation of Canada (for details of this foundation review the section on Research Support).

\section{Manpower issues}

Manpower issues played an important role during the past 25 years. In the 1960s, based on the report of Justice Emmett Hall, it was generally accepted that there was an underproduction of physicians in general, and this was also the case for gastroenterologists. Universities were requested to increase enrollment of medical students, and gastroenterology programs were encouraged to enroll a greater number of trainees. The situation changed in 1970 when Dr Ramsay Gunton, Chairman of the Specialty Development and Manpower Committee of the Royal College published his review (17). Although Dr Gunton stated that his finding "does not necessarily represent Royal College policy or affirmed data" and that "the establishment of physician/population ratio and estimates of requirements based on local opinion is imprecise", he concluded that there was an over-production of gastroenterologists.

The statistics quoted are interesting, as Dr Gunton suggested that there was a need of one per 50,000 population for endocrinologists and only one per 70,000 for gastroenterologists. A com- bined Government, Royal College and CMA Committee, the 'Requirements Committee on Physician Manpower,' was established to review Canadian manpower needs in the specialties. To respond to this Committee the CAG established an 'Advisory Committee on Manpower' under the chairmanship of Dr Alan Gilbert. The report of this Advisory Committee of the CAG was considered by the Requirements Committee to be one of the most illustrious of the approximately 30 working party reports. In spite of this, the opinion of the main committee - there are too many gastroenterologists - remained unchanged.

A second review proving the need for more gastroenterologists was submitted by Dr Larry DaCosta. The major problem in predicting future manpower needs according to Dr DaCosta's committee was the difficulty in determining a baseline, ie, who (at the time of the survey), was a practising gastroenterologist. The committee found the CMA data base inaccurate, because it was compiled without specific prerequisites. These prerequisites were established by the committee and the list prepared by them was compared with that prepared by the CMA.

The final outcome of this work is shown in Table 25 and, based on regional predictions of program directors and practising gastroenterologists, the required numbers needed to reach a desirable gastroenterology/population ratio is shown in Table 26. Based on the expected retirement age and many other factors (eg, more part-time physicians, changes in physicians' life expectations, increasing age of patients, more complex diagnostic and therapeutic procedures, and work involved with patients before and after liver transplants etc) the CAG committee demonstrated a much higher need for gastroenterologists than was suggested by the joint CMA, RCPSC and government 'Requirements Committee on Physicians Manpower'. Despite these excellent submissions, the projected manpower requirements for gastroenterology were reduced, and the support for gastroenterology residents has been cut by most provinces. 
TABLE 25

Gastroenterologist:population ratio in 1987

\begin{tabular}{|c|c|c|c|c|c|c|c|c|c|c|c|}
\hline & \multicolumn{2}{|c|}{ Region 1} & \multicolumn{2}{|c|}{ Region 2} & \multirow{2}{*}{$\begin{array}{c}\text { Region } 3 \\
\text { Ontario }\end{array}$} & \multirow{2}{*}{$\begin{array}{c}\text { Region } 4 \\
\text { Quebec }\end{array}$} & \multicolumn{4}{|c|}{ Region 5} & \multirow{2}{*}{ Canada } \\
\hline & $\mathrm{BC}$ & Alberta & Sask & Manitoba & & & PEI & NB & Nfld & NS & \\
\hline Present number & 24 & 26 & 8 & 13 & 128 & 124 & 0 & 7 & 8 & 11 & 349 \\
\hline Number per region & \multicolumn{2}{|c|}{50} & \multicolumn{2}{|c|}{21} & 128 & 124 & \multicolumn{4}{|c|}{26} & 349 \\
\hline $\begin{array}{l}\text { Number per popula- } \\
\text { tion ratio }\end{array}$ & $1: 121,250$ & $1: 91,230$ & $1: 126,380$ & $1: 82,680$ & $1: 71,910$ & $1: 52,980$ & $0: 126,800$ & $\begin{array}{c}1: 101,48 \\
0\end{array}$ & $1: 70,950$ & 1:79,710 & $1: 73,060$ \\
\hline $\begin{array}{l}\text { Number per popula- } \\
\text { tion region }\end{array}$ & \multicolumn{2}{|c|}{$1: 105,640$} & \multicolumn{2}{|c|}{ 1:99,330 } & 1:71,910 & 1:52,980 & \multicolumn{4}{|c|}{$1: 87,750$} & $1: 73,060$ \\
\hline
\end{tabular}

BC British Columbia; NB New Brunswick; Nfld Newfoundland; NS Nova Scotia; PEI Prince Edward Island; Sask Saskatchewan

TABLE 26

Recommended gastroenterologist:population ratio for 1986

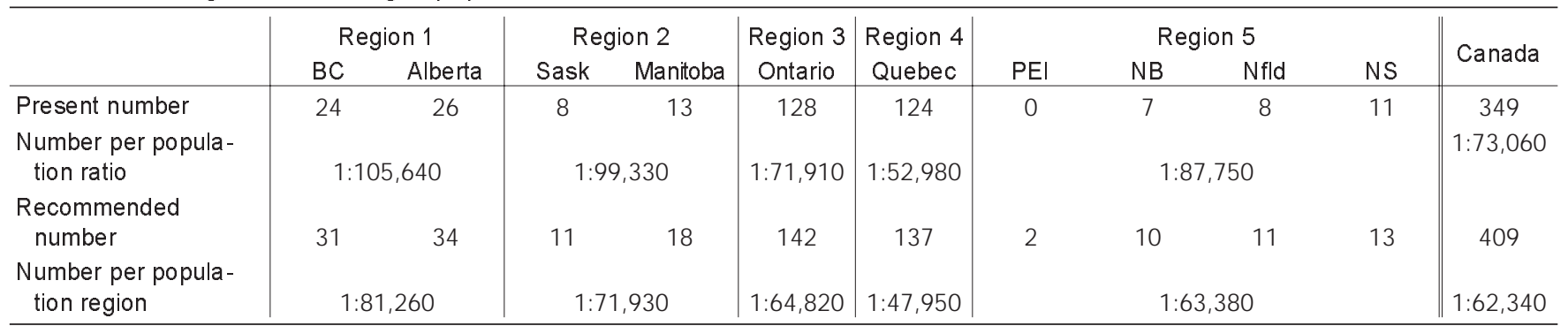

BC British Columbia; NB New Brunswick; Nfld Newfoundland; NS Nova Scotia; PEI Prince Edward Island; Sask Saskatchewan

As usual, issues that appeared to have been settled are constantly being reopened by government. In 1989 the Federal/Provincial/Territorial Conference of Deputy Ministers of Health $(\mathrm{CDMH})$ decided to seek a review of the regional and national approaches to physician resource policy in Canada in order to establish a national, and in some cases regional, strategy of action for physician manpower. In 1990, Morris $\mathrm{L}$ Barer, $\mathrm{PhD}$, from the Centre for Health Services and Policy Research of the University of British Columbia and Greg L Stoddart, $\mathrm{PhD}$, from the Centre of Health Economics, McMaster University, (Hamilton, Ontario) were commissioned by the $\mathrm{CDMH}$ to prepare a strategy discussion addressing the physician resource management problems. After minimal consultation with the profession and none with leaders of the specialties (eg, no contact with $\mathrm{CAG}$ ), in the summer of 1991 these health economists submitted to the CDMH a report on future physician management (18).

Among other statements, the report recommended a $10 \%$ reduction in the enrollment of students to medical schools and a simultaneous reduction in residency posts by $10 \%$. This report was discussed at the $\mathrm{Bi}$-Annual Meeting of Subspecialties of the RCPSC. Dr Steven Collins was the CAG representative. The RCPSC had a written response to the Barer Report in December 1991 and was scheduled to respond in January 1992. The RCPSC made a presentation along with five other national medical organizations to the Ministers of Health Conference in Banff, Alberta, on January 27, 1992. In spite of these presentations the BarerStoddart report was accepted by the $\mathrm{CDMH}$ and the proposed changes are now being put into action by the different provincial governments. Thus, planning for manpower has been now fully removed from the hands of physicians.

\section{Research support}

Stimulation of basic and clinical research was one of the most assiduously pursued objectives of the Association. As early as 1963, Dr McKenna was appointed Chairman of a Fund Raising Committee. Unfortunately, funds necessary to support the legal expenses needed to establish a charitable organization were not available, and Dr McKenna's efforts did not succeed. During the reorganization of the Medi- cal Research Council of Canada (MRC) in 1968, the CAG requested that the MRC should establish a gastroenterology panel. This request was not granted, and even today the panel dealing with gastroenterology consists of a combined group of researchers in gastroenterology, hematology and nephrology with only three gastroenterologists usually on the panel. With the recent appointment of Dr Henry Friesen as President of MRC, 'the Mission', organization and peer review processes of the Council are now being reviewed and hopefully the CAG may make successful representation for establishment of an extended Gastroenterology Committee.

In addition to grants from MRC, research in liver diseases has been supported by the CFDL. The CFIC was established in 1974. It provides operating funds for research in intestinal diseases. Furthermore, after stiff competition among university gastroenterology units, on the basis of a recommendation from an International Advisory Committee, the CFIC established two major Intestinal Disease Research Units, one at McMaster University and the other at the University of Calgary (Calgary, Alberta). The original direc- 
tor of the McMaster Unit was Dr Richard Hunt and presently the unit is directed by Dr Steve Collins, and the director of the Calgary unit is Dr Grant Gall. These units have greatly contributed to the understanding of the effect of inflammation on intestinal physiology and pathology.

For training of investigators in the field of gastroenterology, studentships and fellowships are available from MRC. These are adjudicated by the MRC with no input from the CAG. During the past few years the CAG was successful in obtaining funds for a summer studentship from SmithKline Beecham, and for research fellowship support from Merck Frosst Canada Incorporated and from Janssen Pharmaceutica. The recipients for these fellowships are judged by the CAG Research Committee on a yearly basis and the awards are given to the applicant based mainly on the training and background of the candidate.

A very different competition for research fellowships was initiated by Glaxo Canada Inc. This competition was for ongoing research fellowship support provided to selected university gastroenterology training programs. The objective and method of adjudication of this three-year fellowship was based on the successful achievements of the two CFIC intestinal diseases research units. Thus, the objective of the Glaxo Research Fellowship in Gastroenterology was to provide training which would lead to the establishment of a core of clinician investigators in Canadian university centres. The concept of the fellowship was that Fellows will develop their research skills best in well-supervised units where there was close cooperation between clinical and basic science training.

It was initiated as a pilot project at Queen's University in 1985 and after its apparent success (two of three trainees entered academic gastroenterology), in 1988 all Canadian university centres were invited to compete. The Centres were judged by an international panel. Five units received these Fellowships: University of Alberta (ABR Thomson), University of Calgary (EA Shaffer), McMaster Univer- sity (RH Hunt), University of Toronto (Peter R Durie) and Queen's University (IT Beck). In 1989 a second competition was opened and fellowship support was provided to the pediatric units of St Justin Hospital in Montreal, Quebec (C Roy) and the Department of Pediatrics at the University of Calgary (GD Gall). These fellowships have been of major importance in developing clinical scientists in the field of gastroenterology, and have helped maintain and develop further these training programs.

Within the past two years, in an attempt to establish a comprehensive Canadian Digestive Diseases Foundation, Dr Jean-Francois Loumeau, Director of Medical Communications, Glaxo Canada Inc, approached Drs Richard Hunt, Suzanne Lemire, Ivan Beck and Alan Thomson with a proposal which indicated that to improve long term financial support for gastroenterology, Glaxo Canada was prepared to support financially the expenses, including the legal expenses of, establishing a Digestive Diseases Foundation of Canada.

The purpose of this Foundation will be to raise funds for the support of research, education and patient care for people suffering from diseases of the digestive tract. After negotiations with the CFIC and CFDL, an organizational chart has been developed which includes input from the above charitable organizations. The Medical Advisory Board consists principally of the members of the CAG Board. Thus, 28 years after the first attempt by Dr McKenna to establish such a foundation (which failed at that time because of lack of funds), the establishment of the Digestive Diseases Foundation of Canada has now been included into the strategic plan of the CAG and it appears funds will be available for its initiation.

The Journal of the Association

Since the late 1970s, the CAG needed to publish Canadian articles on gastroenterology, proceedings of symposia held under the aegis of the CAG and abstracts of the Annual Meeting. In 1982 Dr Carl Goresky, the new editor of Clinical and Investigative Medi- cine (CIM) wrote to our President, Dr Gordon Forstner, to request that CIM become the official journal of the CAG. On the basis of this correspondence the Board accepted CIM as CAG's journal. This agreement entailed that the name of CAG should appear on the cover of the journal in both languages and that a member of the Governing Board should sit on the journals Editorial Board. Although Dr Eldon Shaffer was on the Board of CIM, the Journal did not carry the name of the CAG, and editorial input from the CAG was minimal.

In 1986 Drs Alan Thomson and Noel Williams indicated that a new journal The Canadian Journal of Gastroenterology (CJG) will be published. They stated that the Editor would be prepared to publish proceedings of symposia and abstracts at no cost to the Association. Drs Thomson and Williams would be Editors-in-Chief with an elite group of CAG members serving as Associate Editors and a Canadian and international panel as members of the Editorial Board. They suggested that this Journal should be accepted as the official journal of the CAG. There was considerable discussion regarding the role of the CAG in this journal, in particular because the publisher's desire was to give control of the editorial board and content to the Association. Unfortunately, because of previous commitments to CIM, the Board concluded it could not accept the CJG as its official journal. However it was decided that the CAG should fully support and encourage the new CJG with active participation on the Editorial Board and by giving guidance to editorial policy. Since its establishment, thanks to the hard work of its Editors (Drs Thomson and Williams) the CJG has grown and prospered. It published many symposia of the Association (11-15), and recently has achieved listing in Current Contents. The issue of re-examining the possibility of making the CJG the official publication of the CAG has been rediscussed in 1991. This year's president, Dr Suzanne Lemire, appointed Dr Des Leddin to form a committee which should review 
and report to the 1992 Board Meeting on this issue.

\section{Canadian Association of \\ Gastroenterology-sponsored textbook in gastroenterology \\ During the past three years, Drs El-} don Shaffer and Alan Thomson were involved in the editing of a CAG sponsored textbook of gastroenterology, First Principles of Gastroenterology, The Basis of Disease and an Approach to Management (19). Chapters were written by Canadians only and the book is being translated by Dr Andre Archambault into French. This text is a major achievement and a tribute to the editors and members of the CAG.

\section{RELATIONS WITH OTHER NATIONAL AND INTERNATIONAL MEDICAL SOCIETIES}

Canadian Medical Association

The first meetings of the CAG were held in conjunction with those of the CMA and close links developed. Once the CAG combined its meeting with the RCPSC, ties with the CMA became less important. Although the CAG had representation at the General Council of the CMA, this representation was sporadic at best (Table 27) mainly because the CMA Council rarely discussed issues related to gastroenterology, and unless the delegate was familiar with the workings of the CMA Council, his or her participation would be ineffective. The financial cost to send the same representative over several years to the CMA meeting, irrespective of where it was held, would have been too expensive. With improved finances, Dr Bruce Yacyshyn has been appointed to attend the 1991 and 1992 CMA Council meetings.

\section{Royal College of Physicians} and Surgeons Of Canada

Since the meeting of the CAG was moved to coincide with that of the RCPSC, very close relationships developed between the two associations. This became even closer once gastroenterology was accepted as a subspecialty. There are many common goals: establishment of an excellent Annual Meeting, training of gastroenterologists, examinations, reviews of programs and many other educational issues (20). For details see Postgraduate Education Committee, Specialty Committee in Gastroenterology, Training and Education Committee, Committee of Program Directors, Education Committee and CAG representative to Maintenance of Competence.

\section{Canadian Society for \\ Clinical Investigation}

Throughout the years the common interest in basic research has led to combining the first part of the CAG meeting with that of the CSCI. Scheduling was not always easy, but the joint abstract form introduced by the Royal College has overcome many of the difficulties.

Other Canadian societies with gastroenterological interests

For many years the CAG has tried to satisfy the different interests of its constituents: basic scientists, endoscopists, hepatologists, medical gastroenterologists, pediatricians and surgeons - this was not always easy. The creation of an endoscopic society was avoided by establishing an Endoscopic Committee. An active Research Committee caters to basic scientists and clinical investigators. The loss of hepatologists to the CASL in a small country like Canada, with few investigators, could have led to a rift in the gastroenterological community. However, the CAG wished the new society well, provided a small token sum to the establishment of the CASL and arranged for joint sessions at the Annual Meeting. Most members of the CASL remained members of the CAG and many individuals may be sitting simultaneously on the boards of both societies.

\section{Canadian Association} of General Surgeons

The establishment of the CAGS has led to a loss of surgical papers to the CAG, but combined sessions with the CAGS during the Royal College Meeting have overcome some of these prob-
TABLE 27

Canadian Association of Gastroenterot ogy representatives to Canadian Medical Association council

\begin{tabular}{lr}
\hline Kippen, Duncan L & $1966-67$ \\
Buchan, Douglas & 1968 \\
Finlay, John & 1969 \\
Bogoch, Abe & 1970 \\
Sidorov, Joseph & 1971 \\
Gillies, Richard & $1972-73$ \\
Finlay, John & 1974 \\
Williams, C Noel & $198 \mid$ \\
Baker, Selwyn & 1986 \\
Roy, Claude & 1987 \\
Yacyshyn, Bruce & $1991-92$ \\
\hline
\end{tabular}

lems. The controversial issues relating to endoscopy have been discussed in the section on the Endoscopy Committee.

\section{The Canadian Association of Gastroenterology}

and its international relations

The CAG became a member of the OMGE and AIGE as of 1962 and 1963, respectively. Canadian gastroenterologists are well-known abroad, thanks to their scientific contributions to the field (21). The Association made several bids to get the World Congress to come to Canada, and this has been reviewed in the section on the International Liaison Committee.

\section{CONCLUSION}

During the past 30 years, the CAG has made tremendous strides. Scientific developments in the field of gastroenterology have been immense $(2,20)$. For those who have started this Association, it has been a great pleasure to observe the resilience with which the CAG has made adjustments to the constantly changing needs generated by the unrelenting developments of the science, understanding, teaching and practice of gastroenterology. Dealing with most of the situations, the Association responded well, but there were areas where it could have done much better. It is hoped that changes during the next 30 years will similarly be excit- 
ing and that the young members who have recetnly joined the Association will bring about the alterations required by the oncoming changes in science and social structure. It is for these young colleagues that the history of the first 30 years has been compiled. History tends to revolve in cycles, and errors committed inthe past are much too often repeated. Hopefully this review will help the next generations to reach the best possible decisions in the future.

ble 5 .

The photograph of Dr McKenna, the
ACKNOWLEDGEMENTS:There are many to whom I would like to express my thanks and appreciation. Family, friends, colleagues and co-workers made it possible for me to write this history. First of all my family - Marjorie (my wife), Cindy (my daughter) and my parents without whose understandingand unbroken support I would not have been able to spend the time needed for the research and writing of this paper. Throughout the years they granted me many extra hours away from the family which allowed me to maintain my clinical and basic research as well as my clinical teaching. This involvement in academic medicine helped me to maintain my relations with colleagues and friends who were in the forefront of Canadian gastroenterology. It was these contacts who allowed me to remain involved, and this involvement provided me with the personal memories needed to write this history.

I would also like to thank my teachers and students. Without the influence of the spirit of McGill University (Montreal, Quebec) of the 1950 s and ' $60 \mathrm{~s}$, the Royal Victoria Hospital (Montreal, Quebec) of that time, my PhD supervisor, JSL Browne - and specifically the teaching and enthusiasm of Richard McKenna-I would never have been so deeply involved in academic gastroenterology. Just as important were my students, who continued to stimulate my enthusiasm. Without my pride in their achievements I could not have enjoyed medicine to the same extent that I did during the 30 years which provided the basis for this history. I am proud of those who are practising outstanding clinical gastroenterology in all areas of the world and admire those who are investigators and teachers in Canadian and American universities.

I am most thankful to my colleagues at Queen's University (Kingston, Ontario) especially Larry DaCosta and Peter Dinda, who helped in all aspects of my career, and to my previous trainees, Bill Depew, Bill Paterson, Steve Vanner and Mikael Buell, who have all made me proud of their achievements. Drs Douglas (Doug) Kinnear, John M (Jack) Finlay, Alan Thomson and Larry DaCosta read this manuscriptand I am grateful for their suggestions. I am grateful to Dr lain Cleator, President of the CAG in 1989, who persuaded me to accept the challenge of writing the chapter in the History of the Association for Dr Morley's book and to Dr Eldon Shaffer and Suzanne Lemire, Presidents of 1990 and 1991, respectively, for their support and stimulus to accept to write the history of the first 30 years of the CAG. My thanks are also due to Dr Alan Thomson, one of my most cherished previous students, for his editorial in this issue.

Thanks are due to Mrs Ann MacDermaid and Dr Shirley Spragge, Archivists of Queen's University, for classifying and organizing the data which provided the basis of the history of the CAG. More importantly my gratitude is extended to my secretary, Heather Beveridge, for her assistance in obtaining and classify ing the data deposited in the Archives and for her outstanding organization in typing of this manuscript. 


\section{REFERENCES}

1. Beck IT. The Canadian Association of Gastroenterology in Medical Specialty Societies of Canada. Morley TP, ed. Toronto: Associated Medical Services Inc, 1991:323-42.

2. Beck IT. Canadian gastroenterology: Yesterday, today and tomorrow. Clin Invest Med 1982;5:93-107.

3. Sidorov JJ. Evaluation of Training Programs in Clinical Gastroenterology, Canadian Experience, 1971-1981. Scand J Gastroenterol 1988;23 (Suppl 144):82-5.

4. Gillies RR, Perey, B, Beck IT. Gastrointestinal endoscopy - boon or beast? Can Med Assoc J 1976;114:589-90.

5. Beck IT, Crispin JS, Groll A, Sherbaniuk RW. Gastrointestinal Endoscopy: Criteria for Training Doctors. CGA Committee on Endoscopy. Ont Med Rev 1975;42:559-61.

6. Thomson ABR, DaCosta LR, Watson WC. Modern Concepts in Gastroenterology, vol 1. New York: Plenum Publishing Corporation, 1986.

7. Thomson ABR, Shaffer E. Modern Concepts in Gastroenterology, vol II. New York: Plenum Publishing Corporation, 1989.
8. Shaffer E, Thomson ABR. Modern Concepts in Gastroenterology, vol III. New York: Plenum Publishing Corporation, 1992.

9. Beck IT, Sinclair DG. The Exocrine Pancreas. Proceedings of Symposium held at Queen's University, Kingston, Ontario, 1969. London: JA Churchill, 1971.

10. Lacerte M. Le Symposium international sur l'alcool et les maladies de l'appareil digestif. La Vie medicale au Canada français. 1977;6:1019-31.

11. Sutherland L, Williams CN. Trends in Inflammatory Bowel Disease Therapy 1986. Proceedings of a Symposium, Montreal, 1986. Dig Dis Sci 1987;32(Suppl):5S-107S.

12. Thomson ABR, Williams CN. Trends in Inflammatory Bowel Disease Therapy 1988. Proceedings of a Symposium, Lake Louise, Alberta. Can J Gastroenterol 1988;2(Supp1):1A-119A.

13. Groll A, Depew W. Modern concepts in nutritional support - 1989 .

Symposium, Queen's University, Kingston, 1989. Can J Gastroenterol 1990;4(Supp1):1A-111A.

14. Thomson ABR, Williams CN. Trends in Inflammatory Bowel Disease Therapy 1990. Proceedings of a Symposium, Halifax, Nova Scotia. Can J Gastroenterol 1990;4:261-483.

15. Marcon N, Haber G, Kortan P, Kandel G. Proceedings of the Fourth International Course on Therapeutic Endoscopy. The Wellesley Hospital, Toronto, 1989. Can J Gastroenterol 1990;4:527-667.

16. Beck IT, Connon J, Lemire S, Thomson ABR, and other participants. Canadian Consensus Conference on the Treatment of Gastroesophageal Reflux Disease. Can J Gastroenterol 1992;6:277-89.

17. Gunton RW. Manpower Needs in Internal Medicine. Ann R Coll Phys Surg Canada 1973;6:136-42.

18. Barer ML, Stoddart G.L. Toward Integrated Medical Resource Policies for Canada: 1. Background, process and perceived problems. Can Med Assoc J 1992;146:346-51.

19. Thomson ABR, Shaffer EA, eds. First Principles of Gastroenterology. The Basis of Disease and An Approach to Management, Sponsored by the Canadian Association of Gastroenterology. Mississauga: Astra Pharma, 1992.

20. Shephard DAE. The Royal College of Physicians and Surgeons of Canada, The Pursuit of Unity, 1960-1980. Ottawa, 1985.

21. Kirsner JB. The Development of American Gastroenterology. New York: Raven Press, 1990. 


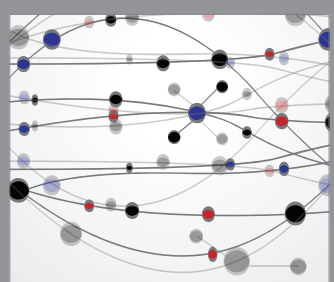

The Scientific World Journal
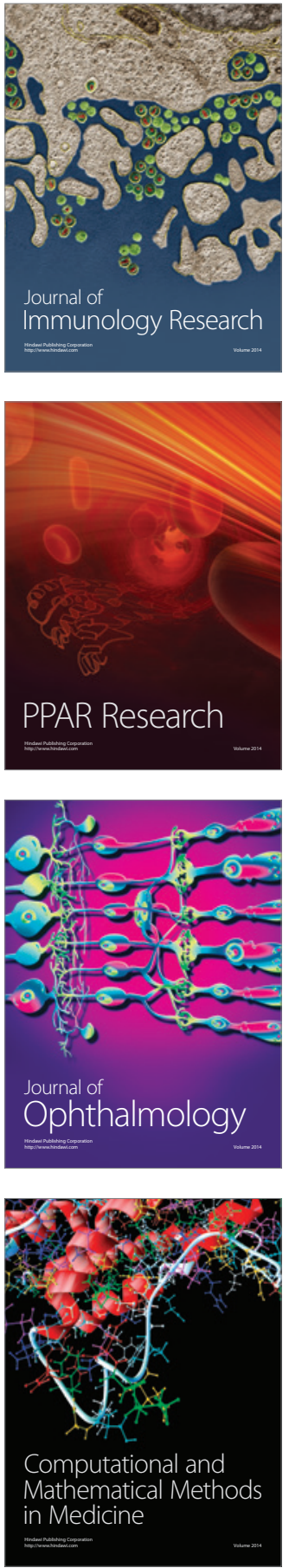

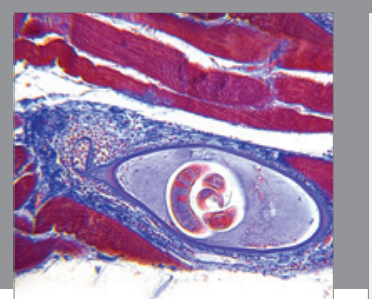

Gastroenterology Research and Practice

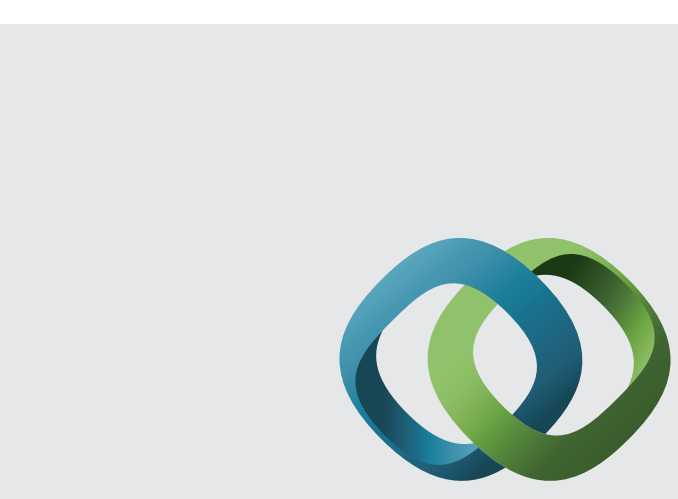

\section{Hindawi}

Submit your manuscripts at

http://www.hindawi.com
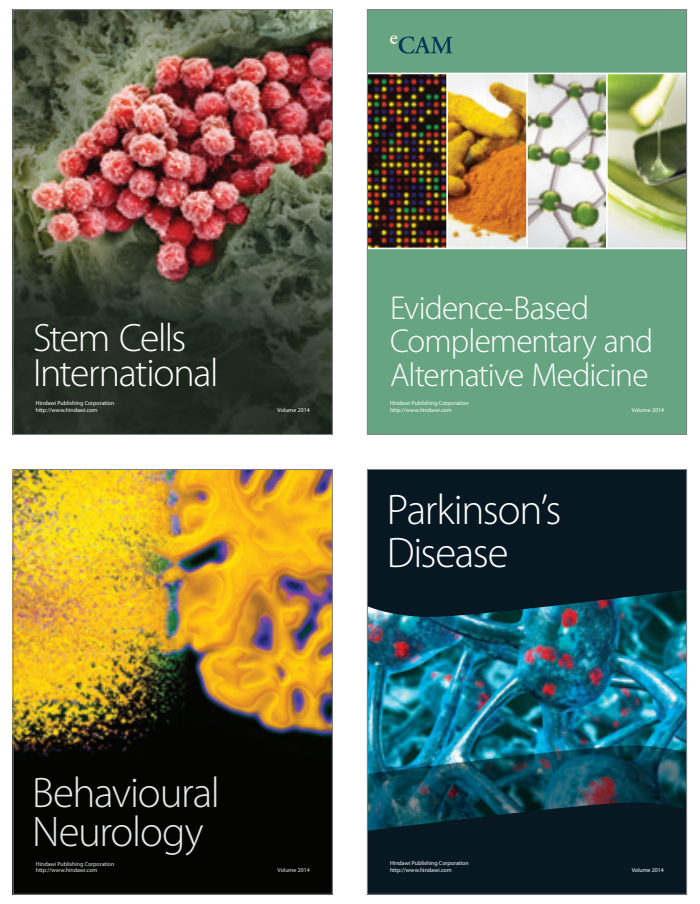
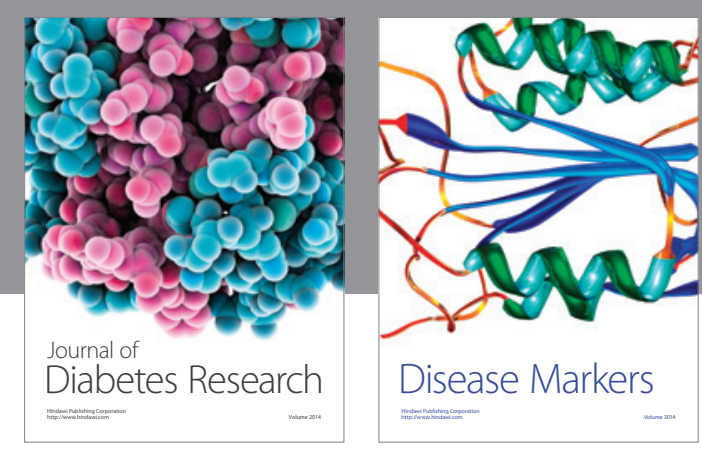

Disease Markers
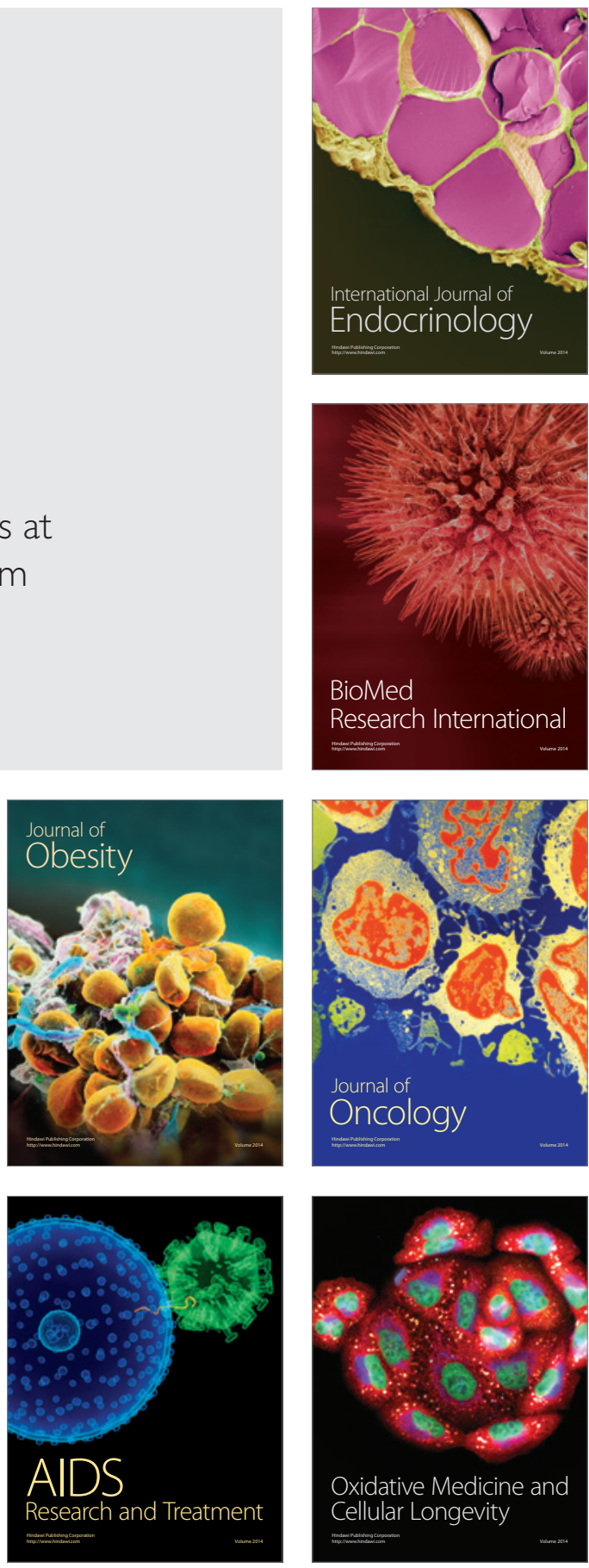